
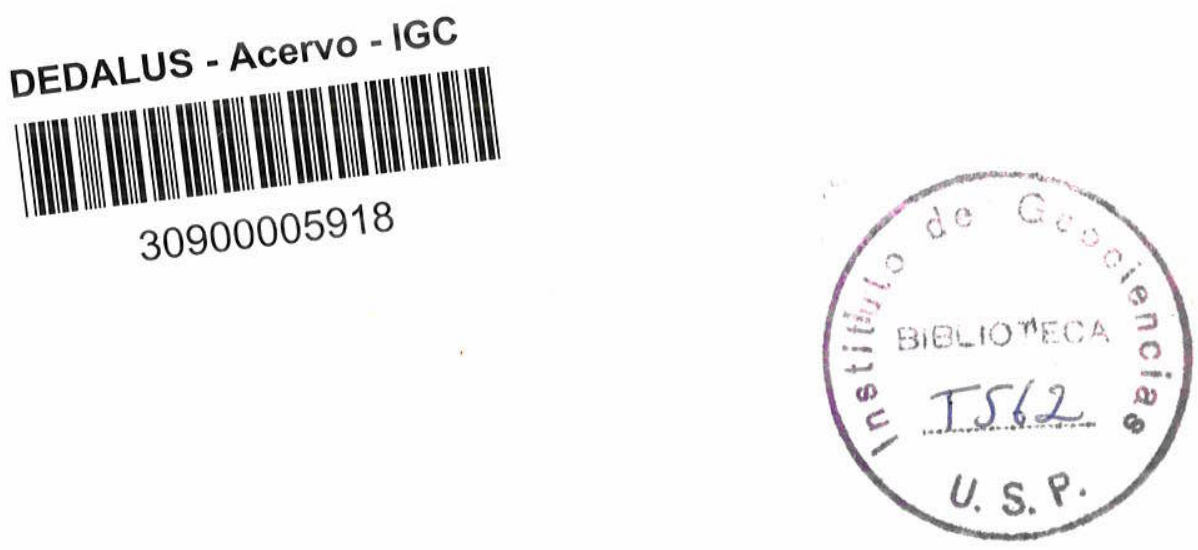

\title{
MINERAIS PESADOS DAS SEQUENCNIAS ARENOSAS PALEOZÓICA E MESOZÓICA NO CENTRO-LESTE DO ESTADO DE SÃO PAULO
}

Dissertação de Mestrado apresentada ao Instituto de Geociências da Universidade de São Paulo.

Orientador :

Prof. Dr. Paulo Milton Barbosa Landim 


\section{INDICE}

pāgina

1. INTRODUÇAO.

2. GEOLOGIA DA AREA ESTUDADA.

2.1. Rochas Sedimentares e Igneas..................... 2

2.1.1. Formações Itarare e Aquidauana.............. 2

2.1.2. Formação Pirambōia.................. 3

2.1.3. Formação Botucatu.................. 4

2.1.4. Formação Serra Geral e rochas intrusivas

bäsicas associadas..................... 5

2.1.5. Formação Bauru..................... 5

2.2. Embasamento Cristalino.................... 6

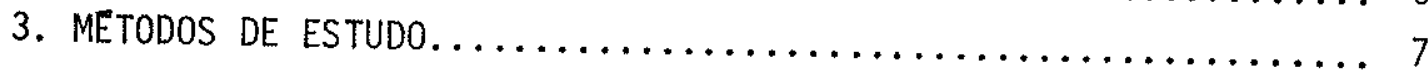

3.1. Coleta de amostras no campo.................. 7

3.2. Preparação das amostras no laboratōrio............ 7

3.2.1. Minerais pesados................... 7

3.2.2. Minerais leves......................13

3.3. Determinação dos minerais e feições morfoscōpicas.......13

3.4. Escala de abundāncia dos minerais.................. 14

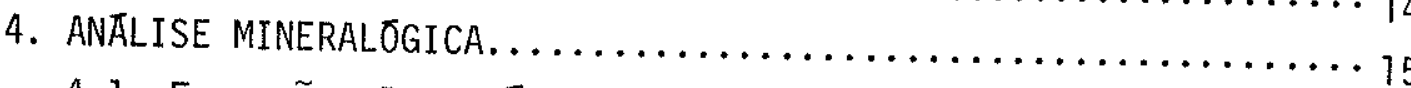

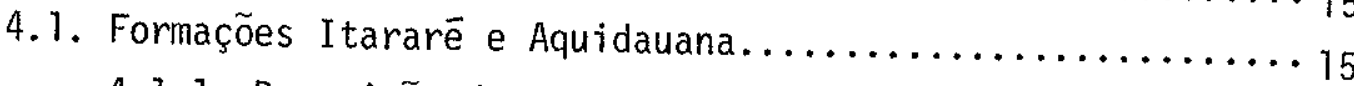

4.1.1. Descrição dos minerais pesados............. 15

4.1.2. Descrição dos minerais leves................ 19

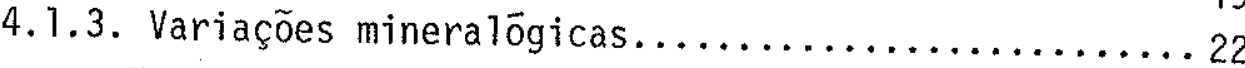

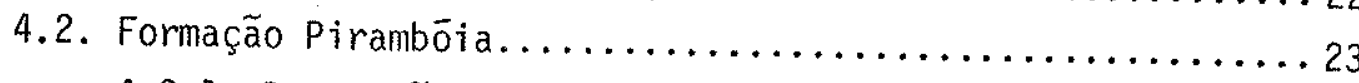

4.2.1. Descrição dos minerais pesados.............23

4.2.2. Descrição dos minerais Teves............... 26

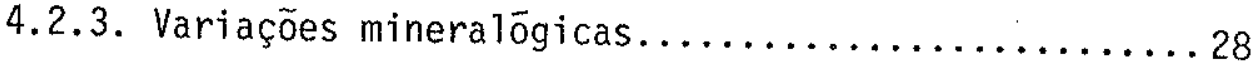

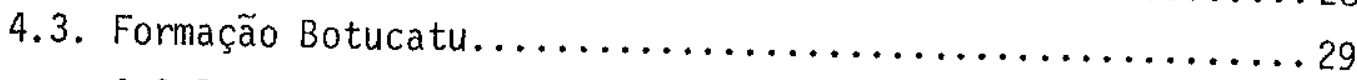

4.3.1. Descrição dos minerais pesados..............29

4.3.2. Descrição dos minerais leves ............... 37

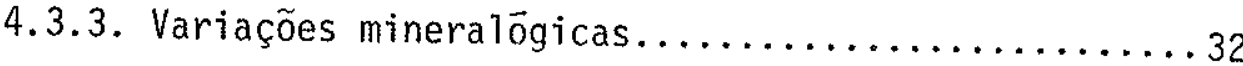

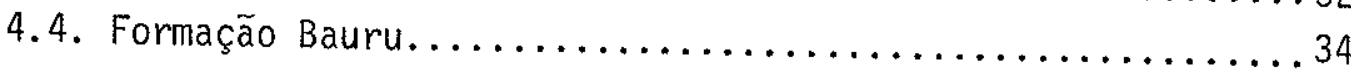

4.4.1. Descrição dos minerais pesados............. 34

4.4.2. Variações mineratōgicas................. 38

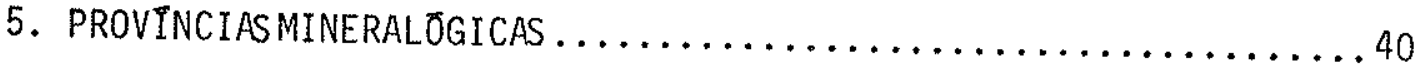

5.1. Formações Itarare e Aquidauana................ 40

5.1.1. Provincia A........................ 


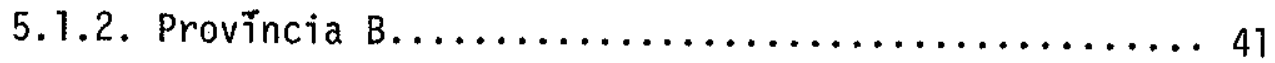

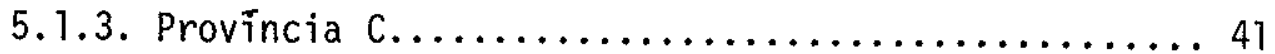

5.2. Formações Piramböia e Botucatu................. 44

5.2.1. Província A...................... 44

5.2.2. Província B....................... 44

5.3. Formação Bauru........................ 47

5.3.7. Provincia A...................... 47

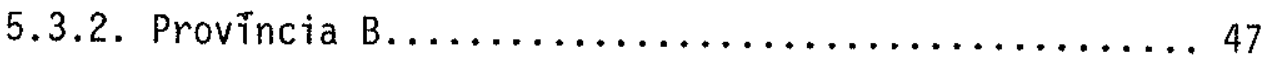

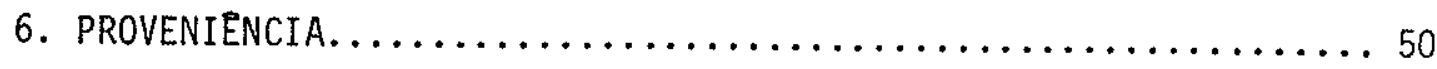

6.1. Estabilidade mineral...................... 50

6.2. Maturidade dos arenitos.................... 52

6.2.1. Maturidade mineralögica................ 52

6.2.2. Maturidade textural.................. 53

6.2.3. Maturidade nos värios arenitos e respectivos controles geológicos................... 53

6.3. Maturidade dos minerais pesados transparentes não micáceos.............................. 55

6.4. Minerais e rochas fontes................... 58

6.4.1. Assemblëias de Minerais e suas rochas fontes..... 58

6.4.2. Minerais uitra-estäveis arredondados masca rando suas rochas fontes................ 58

6.4.3. Rochas fontes......................61 61

6.4.3.1. Arcōsios e subarcōsios no topo do pacote superior e no pacote inferior da Formação Itararé............61 61

6.4.3.2. Quartzo-arenitos da Formação Aqui dauana................................... 61

6.4.3.3. Subarcōsios do pacote superior da Formação Itararē e maioria dos subarcōsios da Formação Aquidauana......63

6.4.3.4. Quartzo-arenitos e subarcósios das formações Itararē e Aquidauana nas regiões de Americana e Araras...........6 64

6.4.3.5. Subarcósios e quartzo-arenitos das formaçōes Piramböia e Botucatu ........66 64

6.4.3.6. Arenitos da Formação Bauru ..........65 65

7. FATORES GOVERNANDO A OCORRENCIA DE MINERAIS .............66

7.1. Abrasão seletiva........................... 66

7.2. Seleção hidräulica......................66

7.3. Intemperismo............................ 67 
7.4. Dissolução intra-estratał $\ldots \ldots \ldots \ldots \ldots \ldots \ldots \ldots \ldots \ldots$

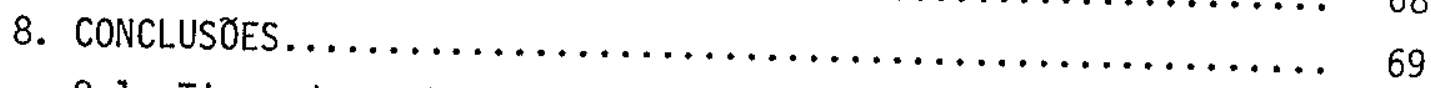

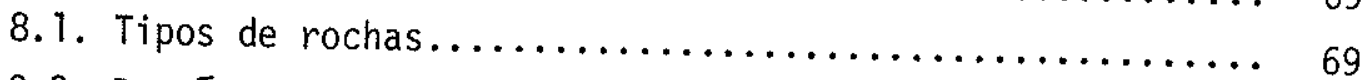

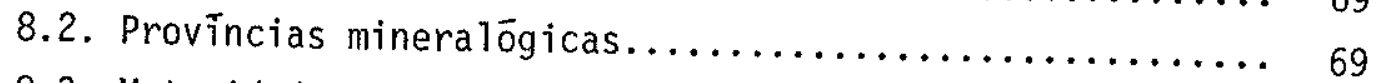

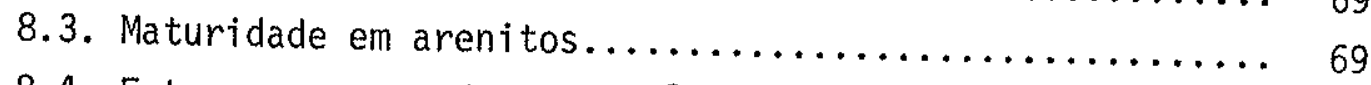

8.4. Fatores governando a ocorrēncia de minerais......... 70

8.5. Rochas fontes dos arenitos e suas condições

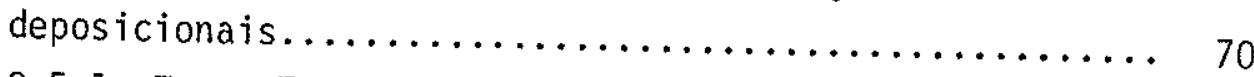

8.5.1. Formaçöes Itararē e Aquidauana............ 71

8.5.2. Formações Piramböia e Botucatu............ 72

8.5.3. Formação Bauru..................... 72

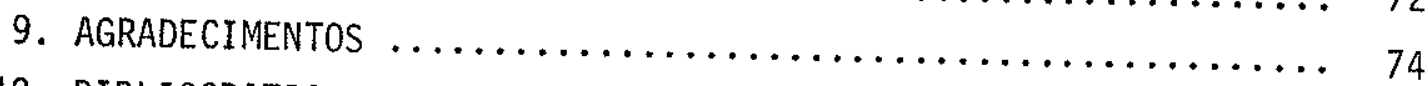

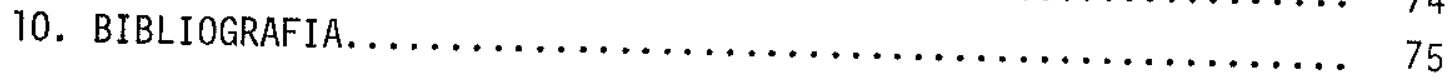




\section{MINERAIS PESADOS DAS SEQÜENCIAS ARENOSAS PALEOZOICA \\ E MESOZOICA NO CENTRO-LESTE DO ESTADO DE SAO PAULO}

\section{INTRODUÇAO}

A coluna estratigräfica das seqüências paleozöica e meso zöica da Bacia do Paranā no Centro-Leste do Estado de São Paulo ē constituĩ da pelos grupos Tubarão, Passa Dois, São Bento e Formação Bauru. Nesta re gião, os trēs grupos tem sido divididos em oito formações: Itararē, Aquidaua na, Tatūi, Irati, Estrada Nova, Piramböia, Botucatu e Serra Geral, sendo os arenitos bem desenvolvidos nas formaçöes Itararē, Aquidauana, Piramböia, Botucatu e Bauru.

Diversos trabalhos têm sido feitos em mapeamento fotogeolo gico, estratigrafia, tectōnica, geomorfologia e geologia econômica da fai $x a$ de ocorrência dos arenitos dessas formações. Estudos sobre a mineralo gia desses arenitos, contudo, tēm sido bastante raros. Alguns trabalhos que se ocuparam da mineralogia dessas rochas são os seguintes. Carvalho (1954) que apresentou dados sobre a petrografia e a origem da Formação Botu catu nas rodovias Botucatu - Conchas e Piraju - Fartura; Amaral (1961) que estudou a silicificação intersticial de arenitos da Sërie Itarare em algu mas localidades de Varnhagen; Paraguassu (1968) que realizou estudo sobre a sedir.entologia, estruturas e silicificação da Formação Batucatu na região de São Carlos; o trabalho desenvolvido por wu e soares (1974) nas forma ções Pirambōia e Botucatu mostrou que as associações de minerais pesados, bem como as äreas fontes destas formações são diferentes e coimbra (1976) que promoveu minucioso estudo sobre a proveniência dos sedimentos de forma ção Bauru, a partir de anälises granulomëtricas e estudos de minerais pesa
dos.

No presente trabatho foram estudados os minerais pesados en contrados nos arenitos das formações Itararë, Aquidauana, Piramböia, Botuca tu e Bauru, no Centro-Leste do Estado de São Paulo. Alëm disso, as lãminas delgadas dos arenitos das formaçōes Itararē. Aquidauana, Piramböia e Botuca tu foram tambëm investigados. A figura I mostra o mapa geolögico simplifi cado com a localização das amostras. o objetivo de tal estudo foi determi nar as associações de minerais pesados e leves desses arenitos para utili zä-las na diferenciação genëtica das diversas unidades e no conhecimento das respectivas äreas fontes. 
2. GEOLOGIA DA AREA ESTUDADA

\subsection{Rochas Sedimentares e Igneas}

$\mathrm{Na}$ ārea estudada as rochas sedimentares são representadas pe las formações Itararē, Aquidauana, Tatữ, Irati, Estrada Nova, Pirambōia, Botucatu e Bauru. As rochas ígneas constituem a Formação Serra Geral e as intrusivas bäsicas associadas. Como dito, somente cinco formações apresen tam um desenvolvimento significativo de clästicos grosseiros, ou seja, Ita rarē, Aquidauana, Piramböia, Botucatu e Bauru, cujas caracterĩsticas são apresentadas a seguir.

\subsubsection{Formações Itararë e Aquidauana}

As formações Itararē e Aquidauana na ārea estudada são re presentadas por diamictitos, arenitos, ritmitos, siltitos, lamitos e argi Titos. A espessura do Itararē no Centro-Leste do Estado de São Paulo chega a $1200 \mathrm{~m}$, decrescendo no sentido nordeste.

Os diamictitos, englobando conglomerado lamítico, arenito la mitico conglomerätico e conglomerado arenoso lamítico, ocorrem dominantemen te na parte sudoeste da ārea estudada, intercalados com arenitos e sedimen tos finos. Os corpos variam em forma, tendo espessuras em torno de $5 \mathrm{~m}$. AI guns são maciços, polimîticos, contendo seixos estriados indicando verda deiros tilitos; en sua maioria săo levemente estratificados, contendo muj tas vezes lentes de arenito amarrotadas. Os seixos atingem $30 \%$ em abundän cia, sendo constituídos por litologias resistentes como quartzito, metagrau vaca, metarcôsio, granito, etc. Seixos estriados não são comuns. A matriz arenosa $\vec{e}$ quase sempre predominante e um diamictito com alta porcentagem de finos, isto ē, particulas menores que 62 micra, ē um indício seguro de que se trata de um verdadeiro tilito (Soares e Landim, 1973).

Os arenitos da Formação Itararē, de cor cinza clara a cinza acastanhada, com granulações variāveis, ocorrem predominantemente na parte sudoeste da ärea estudada. Esses corpos arenosos variam tanto em forma e relações com as demais litologias existentes como em dimensões. Exibem di versas estruturas sedimentares singenēticas como marcas ondulares, marcai de sola, estratificação cruzada, estratificação gradacional, etc., e estru 
turas deformacionais plästicas penecontemporāneas à deposição. Texturalmen te, os arenitos são imaturos a submaturos, raramente maturos.

Os sedimentos finos da Formação Itararē, incluindo siltitos, lamitos e argilitos, ocorrem dominantemente na parte sudoeste da ärea estu dada,e apresentam-se tanto bem estratificados como maciços, ritmitos com seixos pingados estão presentes nesta ärea.

$\mathrm{Na}$ parte nordeste da ārea estudada, os sedimentos predomi nantes são arenitos lamiticos e siltitos arenosos, avermelhados, da Forma ção Aquidauana (Soares e Landim, 1973 e Fiori, 1977).

Quanto às relações entre essas rochas avermelhadas da Forma ção Aquidauana e os sedimentos da Formação Itarare do sudoeste da ärea es tudada, as evidências indicam mütuas interdigitações tanto na base como no topo. Isso pode muito bem ser visto na região da Fazenda Pitanga e em Ta tu, Campinas, Leme, Conchal e Mogi-Guaçu. Em todas essas seções observase os sedimentos avermelhados, atribuĩdos à Formação Aquidauana, intercala dos por arenitos, diamictitos e ritmitos de cores acinzentadas.

Esta unidade assenta-se discordantemente sobre o Embasamen to Cristalinoe seucontato superior com Formação Tatuī ê uma discordāncia erosiva.

A idade destas formações deve ser Carbonîfero superior a Per miano inferior, (Andrade e Soares, 1971 e Soares e Landim, 1973).

Baseado na mineralogia dos pesados (figura 3), o Autor divi de a Formação Itarare em dois pacotes: pacote superior e pacote inferior. 0 pacote inferior corresponde aproximadamente ao membro inferior e o supe rior aos membros mëdio e superior, segundo a terminologia de soares et alzi, 1977.

\subsubsection{Formação Pirambōia}

A Formação Pirambōia na ārea estudada ē caracterizada por arenitos de granulação mëdia a muito fina, raramente grosseira, com inter calação de camadas de siltito e folhelho. A espessura desta formação $\overline{\mathrm{e}}$ em torno de $200 \mathrm{~m}$ a $260 \mathrm{~m}$ nas äreas da Rodovia Castelo Branco e Analãn dia e tende a reduzir-se para norte. Na ärea de Franca, a espessura não deve ultrapassar $60 \mathrm{~m}$ (Andrade e Soares, 1971 e Soares et alli, 1973).

Os arenitos Piramböia são principalmente de granulometria mui to fina a mëdia, subangular a arredondada, contendo pouca argila, regular mente selecionada e maturidades textural e mineralögica submatura a matura. Estes arenitos apresentam acamamento plano-paralelo e estratificação cruza 
da planar de porte pequeno a grande, tangencial na base; mais raramente estratificação cruzada acanalada. Apresentam cores amarela- esbranquiçada e avermelhada.

Camadas de siltito e argilito ou folhelho são raras, desde milimëtricas atē $7 \mathrm{~m}$. Geralmente apresentam grãos esparsos de areia e tem cor vermelho-escura a marrom-avermelhada. São maciços ou laminados (Soa res et azzi, 1973).

0 contato da Formação Pirambōia com a Formação Estrada Nova è atravēs de uma discordāncia erosiva e o contato com a Formação Botucatu è gradacional.

Segundo Soares et alli (1973), a idade do Piramböia fica si tuada entre o Triässico inferior e Jurāssico superior.

\subsubsection{Formação Botucatu}

A Formação Botucatu na ārea estudada $\overrightarrow{\mathrm{e}}$ dominantemente cons tituĩda por arenitos de granulação mëdia a fina, com arenitos conglomerä ticos na parte basal da unidade e lamitos arenosos, siltitos e arenitos lamiticos na parte superior. A espessura mëdia $\overline{\mathrm{e}}$ em torno de $60 \mathrm{~m}$, atin gindo $120 \mathrm{~m}$ na Serra de São Pedro (Andrade e Soares, 1971 e Soares et alzi, 1973).

Os arenitos da Formação Botucatu são dominantemente finos a mëdios, sem argila, arredondados a bem arredondados, com grau de sele ção regular a boa, sempre bimodais, e maturidade submatura a supermatura. A estratificação cruzada planar è dominantemente de grande porte e tangen cial na base.

Os arenitos conglomeräticos e grosseiros são friāveis e argi losos. Os seixos presentes são dominantemente de quartzo e quartzito,com tamanho variāvel atingindo ate $10 \mathrm{~cm}$. Os seixos säo tanto angulares como arredondados, alguns ventifactos, e os grãos de areia são sempre arredon dados. Estes depōsitos conglomerāticos apresentam estratificação cruzą da de pequeno a mëdio porte(Soares, 1973).

os sedimentos finos são siltitos argilosos ou arenosos, la mitos arenosos e arenitos lamĩticos, com estratificação incipiente, pla no-paralela e cruzada (Soares, 1973).

Esta unidade assenta-se concordantemente sobre a Formação Piramböia. 0 contato com a unidade superior, isto é, os derrames basal ticos, è complexo em virtude de ocorrêricia de interdigitamento e recorrēn cia das litologias. A idade do Botucatu deve ser Jurässico superior a Cre 
täceo inferior (Soares et alzi, 1973).

\title{
2.1.4. Formação Serra Geral e rochas intrusivas bāsicas associadas
}

\begin{abstract}
A Formação Serra Geral ē uma sequēncia vulcānica constituí da de basaltos toleiticos. Na parte inferior $\vec{e}$ comum a presença de aren tos semelhantes ao Botucatu em finas camadas intercaladas nos derrames ou a inclusão de grandes linguas que refletem o interdigitamento das forma ções Serra Geral e Botucatu. Os conjuntos de derrames superiores apresen tam grande continuidade. A espessura mäxima da Formação Serra Geral na região estudada atinge $400 \mathrm{~m}$ na Serra de Botucatu (Andrade e Soares, $1971)$.
\end{abstract}

As formações inferiores aos derrames da Formação Serra Ge ral no nordeste do Estado de São Paulo sofreram grandes intrusões de dia bäsio, dominantemente sob a forma de sill e mais raramente sob a forma de dique. 0 mais extenso e espesso sill da região, em torno de $100 \mathrm{~m}$ de espessura, $\vec{e}$ o de Borda da Mata, entre Cajuru e São Sebastião de Grama. Grandes diques não ocorrem, mas os pequenos são frequentes (Soares et alzi, 1973).

No diabāsio que constitue o sill de Borda da Mata ocorrem texturas quase equigranulares, localmente com cristais de atē mais de 1 $\mathrm{cm}$, dando à rocha o aspecto de gabro. Na ramificação de Cajuru $\overline{\mathrm{e}}$ comum a textura ofitica, o que $\vec{e}$ característica de rochas intrusivas (Leinz,
1949 ).

Estas rochas extrusivas e intrusivas bäsicas foram origi nadas num perĩodo de intenso vulcanismo basältico de fissura, correspon dendo ao Jurässico superior e Cretāceo inferior (Amaral et alzi, 1966).

\subsubsection{Formação Bauru}

A Formação Bauru, posterior aos derrames basälticos do Nor deste da Bacia do Parană, foi dividida em dois pacotes: um inferior $\mathrm{e}$ outro superior. 0 pacote inferior e constituĩdo por fäcies de arenitos finos e arenitos argilosos e o pacote superior por fäcies de arenitos sîlticos, calco-conglomerados e arenitos tufäceos (Soares e Landim, 
1976). Na ārea estudada, a espessura māxima ē da ordem de $200 \mathrm{~m}$, em Mon te Alto. A partir daỉ, decresce para norte e sul e desaparece a leste.

Os arenitos são dominantemente mëdios a finos, argilosos, de cor castanho-avermelhada, raramente cinza e verde, pobremente selecio nados, ricos em feldspatos e minerais ferro-magnesianos e opacos. Estes arenitos apresentam-se maciços ou com acamamento plano-paralelo e estratificação cruzada acanalada de pequeno porte (Andrade e Soares, 1971 e Soares et alli, 1973).

Os conglomerados, com seixos de basalto, arenitos, lamitos e silex, são maciços, cinza e castanho e pobremente selecionados (Andrade e Soares, 1971).

extensão.

Camadas argi losas vermelhas săo raras, delgadas e de pequena

0 contato da Formação Bauru com a Formação Serra Geral é uma superfície de desconformidade. A idade do Bauru obtida atravēs de dá dos paleontológicos ē Cretāceo superior (Andrade e Soares, 1971).

\subsection{Embasamento Cristalino}

As rochas sedimentares da ārea estudada repousam sobre o $\mathrm{Em}$ basamento Cristalino de idade Pré-Cambriana, representado pelo Grupo São Roque a sudeste da ärea; Grupo Amparo e Grupo Pinhal (Artur et alzi, 1979) a leste; e Grupo Araxā (Penalva e Wernick, 1973) a nordeste. As rochas mais comuns destes grupos são as seguintes: 0 Grupo São Roque $\vec{e}$ consti tuĩdo por filitos, metarenitos, quartzitos e metaconglomerados; o Grupo Amparo ē representado por gnaisses, quartzitos, anfibolitos e granulitos e o Grupo Pinhal por granitóides e migmatitos; o Grupo Araxā $\bar{e}$ constituí do por micaxistos, granada-anfibolitos, anfibolitos e quartzitos. 
3. METODOS DE ESTUDO

3. T. Coleta de amostras no campo

As amostras coletadas na região Centro-Leste do Estado de São Paulo compreendem principalmente arenitos e arenitos conglomeráticos e raramente siltitos arenosos e siltitos. Os tipos de amostragem efetua dos foram: amostragem pontual e amostragem composta.

Foram analisadas 35 amostras pontuais coletadas nas forma çōes Itararē (17) e Aquidauana (18), cujas localizações estão representadas na figura 1 e tabela I.

Devido à pequena quantidade de minerais pesados nas forma ções Pirambōia e Botucatu e à variabilidade encontrada em diferentes veis, foram combinadas diversas amostras coletadas em uma mesma região pa ra formar amostras compostas de 1 a $2 \mathrm{~kg}$ cada uma. Dessa forma, foram com postas 9 amostras, apresentadas na figura 1 e tabela 1 .

Na Formação Bauru, 27 amostras pontuais foram coletadas no noroeste da ärea estudada, sendo 7 amostras da região de 01 impia e 20 amos tras da região de Taquaritinga (figura 1 e tabela I).

Alëm disso, com a finalidade de reconhecimento dos mine rais pesados existentes nas rochas cristalinas da região, 2 amostras foram coletadas: uma de quartzito e outra de gnaisse (figura 1 e tabela I).

A amostragem teve como finalidade obter material para estu do principalmente dos minerais pesados e, secundariamente, dos minerais $1 \bar{e}$ ves dos arenitos daquelas formações.

3.2. Preparação das amostras no laboratörio

\subsubsection{Minerais pesados}

As amostras simples e/ou compostas foram desagregadas ma nualmente ou com 0 auxîlio de almofariz e pistilo, e quarteadas com quar teador simples.

Apōs a desagregação e quarteamento, as amostras de 100 gra mas em peso foram lavadas em peneira com abertura de $0,062 \mathrm{~mm}$, visando 


\section{Tabela 1}

Relação de amostras de sedimentos das formações Bauru, Botucatu, Pirambōia, Aquidauana e Itararē com especificações de procedência e natureza litolōgica.

\begin{tabular}{|c|c|c|c|}
\hline Amostras & Localização & Litologia & Formação \\
\hline 1 & Ibitu & $\begin{array}{l}\text { Arenito calcīfero, granulação variāve 1, maciço, } \\
\text { cor verde }\end{array}$ & \\
\hline $2 a$ & 01 $\overrightarrow{j m p i a}$ & Arenito fino a mëdio, estratificação cruzada & \\
\hline $2 b$ & 01 İmpia & Arenito fino a muito fino, maciço & \\
\hline $2 c$ & 01 impia & Arenito muito fino, calcifero, maciço & \\
\hline 3 & Severinia & Arenito fino, estrâtificação cruzada & \\
\hline 4 & Severinia & $\begin{array}{l}\text { Arenito fino a muito fino, estratificação para- } \\
\text { lela e cruzada }\end{array}$ & \\
\hline 5 & Marcondësia & Arenito muito fino a fino, argiloso, maciço & \\
\hline 6 & Santa Adelia & $\begin{array}{l}\text { Arenito muito fino, com seixos e fragmentos de } \\
\text { osso, cor marrom }\end{array}$ & Bauru \\
\hline 7 & Santa Adelia & $\begin{array}{l}\text { Arenito fino a muito fino com fragmentos de os- } \\
\text { so, cor vermetha }\end{array}$ & \\
\hline $8 a$ & Cândido Rodrigues & Lami to arenoso, maciço, cor marrom & \\
\hline $8 b$ & Cândido Rodrigues & Arenito fino a mëdio, maciço, cor marrom & \\
\hline 9 & Rodovia Taquaritinga para Jurupema & Arenito muito fino a médio, maciço, cor vermetha & \\
\hline 10 & $\begin{array}{l}\text { Cruzamento da Rodovia JabuticabaT- } \\
\text { - Taquaritinga }\end{array}$ & $\begin{array}{l}\text { Arenito fino a médio, maciço ou estratificação } \\
\text { cruzada }\end{array}$ & \\
\hline 11 & Monte Alto & Arenito lamitico, maciço, cor branca & \\
\hline $12 \mathrm{a}$ & Mionte Alto & Arenito fino a médio, maciço, cor vermetha & \\
\hline $12 b$ & Monte Alto & Lamito arenoso, maciço, cor verde & \\
\hline
\end{tabular}


Continuação - Tabela 1

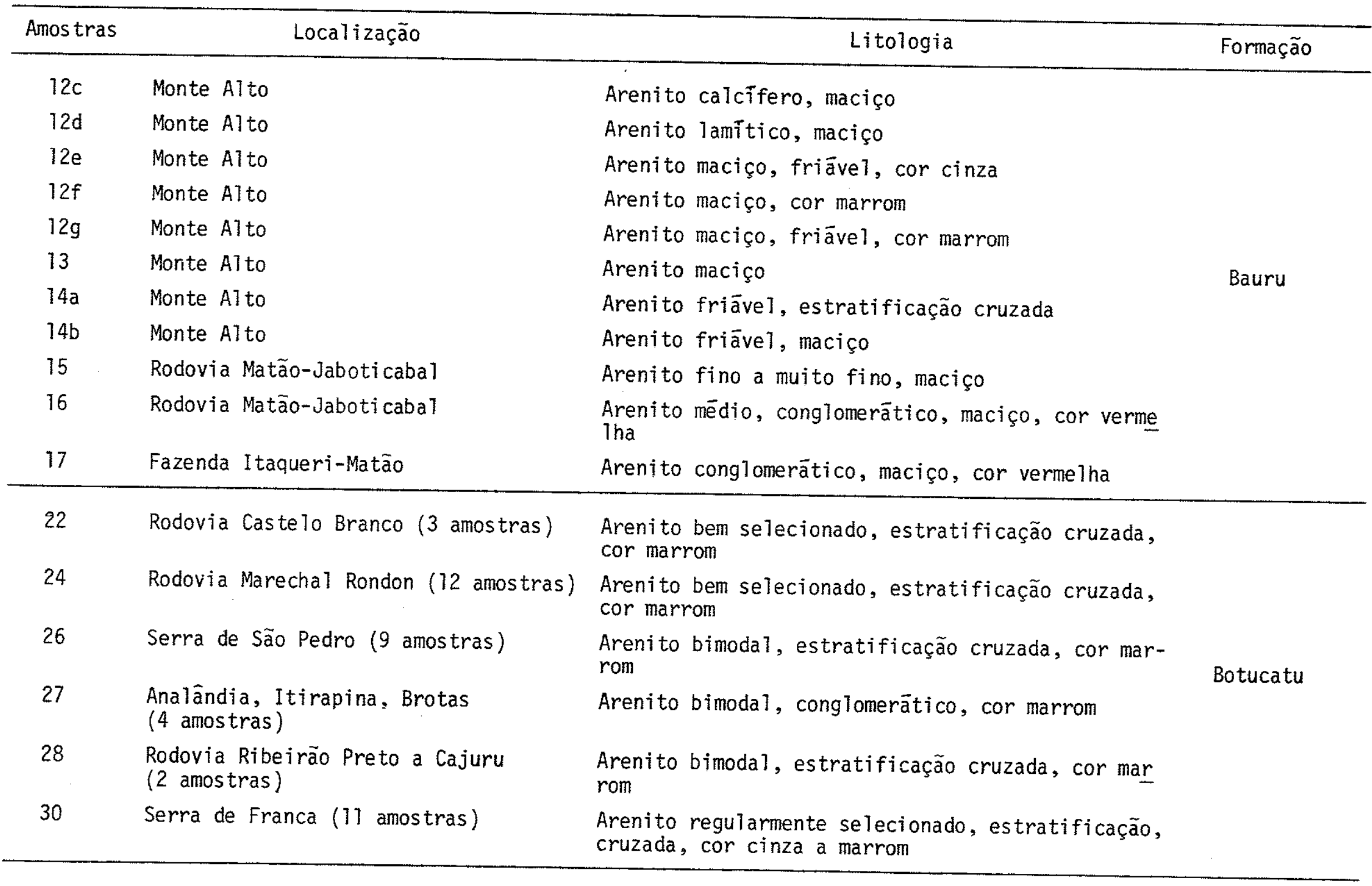


Continuação - Tabela 1

\begin{tabular}{|c|c|c|c|}
\hline Amostras & Loca]ização & Litologia & Formação \\
\hline 21 & Rodovia Castelo Branco (12 amostras) & $\begin{array}{l}\text { Arenito mal selecionado, estratificação cruzada, } \\
\text { cor marrom }\end{array}$ & \multirow{4}{*}{ Piramböia } \\
\hline 23 & Rodovia Marechal Rondon (14 amostras) & $\begin{array}{l}\text { Arenito de seleção regular a boa, estratificação } \\
\text { cruzada, cor marrom }\end{array}$ & \\
\hline 25 & Rodovia Washington Luiz (9 amostras) & $\begin{array}{l}\text { Arenito de seleção regular, estratificação cruza } \\
\text { da, cor marrom }\end{array}$ & \\
\hline 29 & $\begin{array}{l}\text { Rodovia Ribeirão Preto a Cajuru } \\
\text { ( } 1 \text { amostra) }\end{array}$ & $\begin{array}{l}\text { Arenito de seleção regular a boa, estratificação } \\
\text { cruzada, cor marrom }\end{array}$ & \\
\hline 33 & Limeira & $\begin{array}{l}\text { Siltito a arenito muito fino, maciço, cor ar- } \\
\text { roxeada }\end{array}$ & \multirow{7}{*}{$\begin{array}{l}\text { Itararēe } \\
\text { Aquidauana }\end{array}$} \\
\hline 34 & Tatu & $\begin{array}{l}\text { Siltito a arenito muito fino, laminado, cor cin- } \\
\text { za avermelhada }\end{array}$ & \\
\hline 35 & Tatu & $\begin{array}{l}\text { Arenito muito fino a fino, maciço, estratificação } \\
\text { cruzada, cor marrom }\end{array}$ & \\
\hline 36 & Rodovia Anhanguera & $\begin{array}{l}\text { Arenito lamitico, ligeiramente conglomerätico, ma } \\
\text { ciço, cor amarela-acastanhada }\end{array}$ & \\
\hline 37 & Rodovia Anhanguera & $\begin{array}{l}\text { Lamito arenoso ligeiramente conglomerätico, maci- } \\
\text { ço, cor cinza clara }\end{array}$ & \\
\hline 38 & Campinas & $\begin{array}{l}\text { Arenito muito fino a grosseiro, maciço, estratifi } \\
\text { cação cruzada, cor cinza a amarelo-avermelhada }\end{array}$ & \\
\hline 40 & Rodovia Anhanguera & $\begin{array}{l}\text { Arenito muito fino a grosseiro, maciço, cor cinza } \\
\text { a cinza amarronzada }\end{array}$ & \\
\hline
\end{tabular}




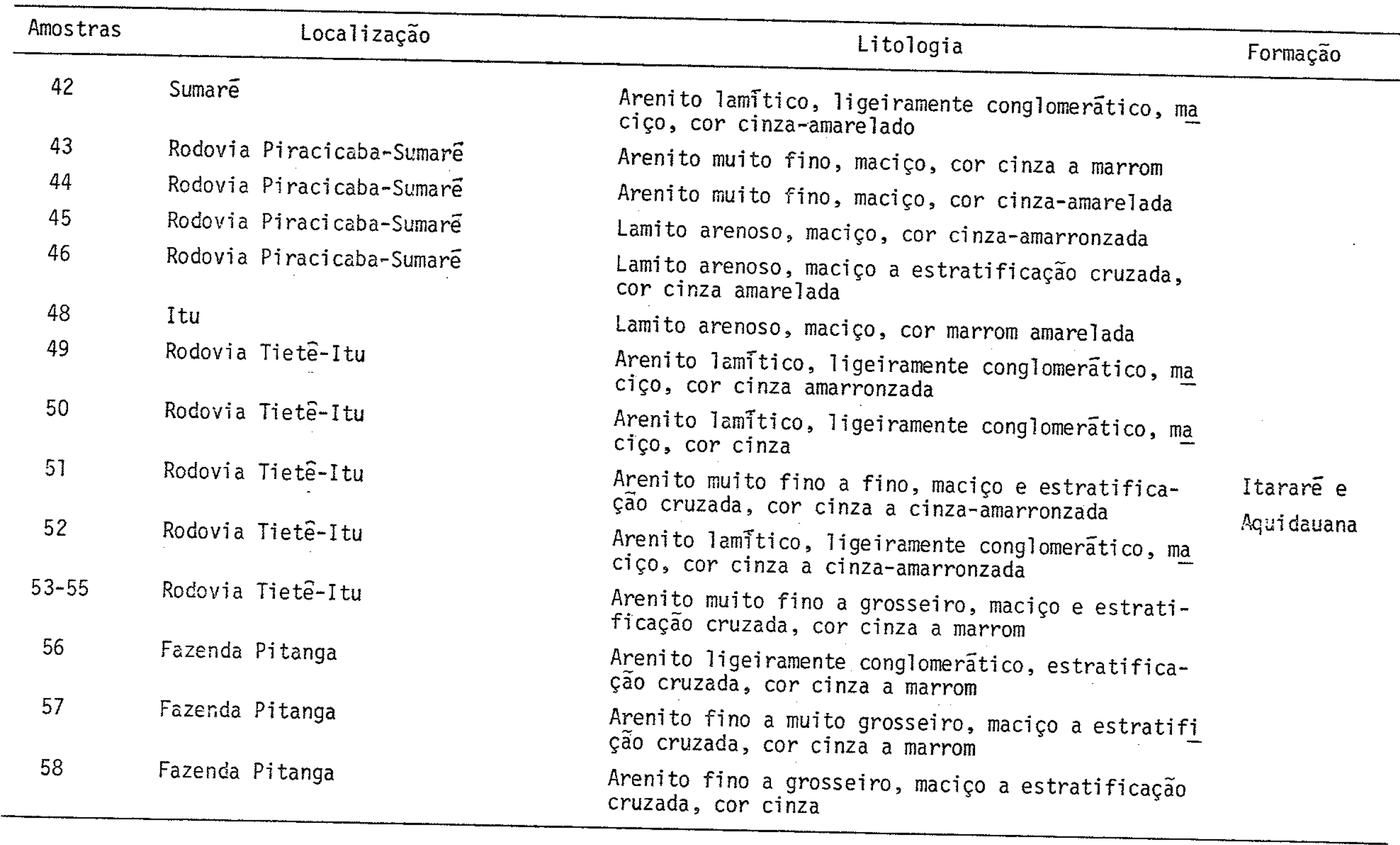


Continuação - Tabela 1

\begin{tabular}{|c|c|c|c|}
\hline Amostras & Localização & Litologia & Formação \\
\hline 59 & Araras & $\begin{array}{l}\text { Arenito fino a muito fino, estratificação cruza- } \\
\text { da, cor cinza-avermelhada }\end{array}$ & \multirow{12}{*}{$\begin{array}{l}\text { Itararēe e } \\
\text { Aquidauana }\end{array}$} \\
\hline 60 & Araras & $\begin{array}{l}\text { Arenito fino a muito fino, estratificação cruza- } \\
\text { da, cor cinza-amarronzada }\end{array}$ & \\
\hline 67 & Rodovia Araras-Mogi Mirim & $\begin{array}{l}\text { Arenito muito fino a grosseiro, maciço, cor ver- } \\
\text { melha }\end{array}$ & \\
\hline 62 & Rodovia Araras-Mogi Mirim & Siltito arenoso, maciço, cor cinza-avermelhada & \\
\hline 63 & Rodovia Araras-Mogi Mirim & $\begin{array}{l}\text { Arenito muito fino a grosseiro, maciço, cor ver- } \\
\text { melha }\end{array}$ & \\
\hline 65 & Aguai & $\begin{array}{l}\text { Arenito muito fino a grosseiro, maciço, cor ver- } \\
\text { melha }\end{array}$ & \\
\hline 66 & Casa Branca & $\begin{array}{l}\text { Arenito fino a mëdio, lamïtico, maciço, cor ver- } \\
\text { melha }\end{array}$ & \\
\hline 67 & Casa Branca & $\begin{array}{l}\text { Arenito fino a mëdio, Tamítico, maciço, cor ver- } \\
\text { melha }\end{array}$ & \\
\hline 68 & Rodovia Casa Branca-Mococa & $\begin{array}{l}\text { Arenito lamîtico, ligeiramente conglomerático, ma } \\
\text { ciço, cor vermelha }\end{array}$ & \\
\hline 69 & Rodovia Cajuru-Mococa & $\begin{array}{l}\text { Arenito muito fino, lamitico, maciço, cor cinza } \\
\text { a vermelha }\end{array}$ & \\
\hline 70 & Rodovia Cajuru-Mococa & Arenito mëdio, lamitico, maciço, cor verme tha & \\
\hline 71 & Rodovia Cajuru-Mococa & Arenito médio, lamítico, maciço, cor vermelha & \\
\hline 72 & Rodovia Mogi Mirim-Itapira & Quartzito & Prē-Cambriano \\
\hline 73 & São João da Boa Vista & Gnaisse intemperizado & Indiviso \\
\hline
\end{tabular}


à el iminação das frações sīltica e argilosa. Posteriormente à secagem , as amostras foram peneiradas a fim de se obter a fração $0,125-0,062 \mathrm{~mm}$ que foi a escolhida para o estudo mineralögico.

A separação entre a fração leve e a pesada foi efetuada em funis apropriados, utilizando-se bromofórmio de densidade $d=2,89$.

A ültima operação consistiu na montagem dos minerais em lâminas, utilizando-se bālsamo de Canadā de indice de refração $n=1,54$.

\subsubsection{Minerais leves}

Os processos detalhados para a preparação de lâminas delga das tem sido amplamente publicados, tornando-se desnecessäria sua apresen tação.

Devido à friabilidade dos arenitos estudados, foi necessārio um tratamento prēvio para endurecê-1os. Uma pequena fatia de cada amostra foi fervida em um recipiente contendo bälsamo do Canadă tendo sido adicio nada pequena quantidade de goma-laca, durante cinco a dez minutos. Algumas amostras mais argilosas foram submetidas duas ou mais vezes a este proces so, no sentido de colar seguramente os grãos de areia para a confecção das lâminas delgadas. Estas, finalmente, foram feitas pelos processos conven cionais.

\subsection{Determinação dos minerais e feições morfoscôpicas}

No estudo da composiçäo mineralögica, foram analisados tan to os minerais pesados como os minerais leves dos arenitos coletados.

Para os minerais pesados, foram estudadas as caracteristicas mineralögicas e contados um mīnimo de 100 grãos por amostra. Apōs a contagem foi realizada uma varredura completa na lâmina. Para algumas amostras em que apareceram dūvidas na identificaçăo dos minerais, os indi ces de refração dos mesmos foram determinados pelo método da imersao. Alēm da determinação dos minerais, foi feita a anālise morfoscópica como arre dondamento e häbito cristalino, e calculados os indices de maturidade mi neralögica.

Para minerais leves, foram identificados e contados 100 grãos por lâmina, e verificadas as caracterîsticas de matriz e cimento. Em seguida, foram medidos o tamanho médio dos grăos e os valores correspon 
dentes ao arredondamento, seguido do cālculo do grau de seleção, maturida de textural e indice de maturidade mineralōgica.

3.4. Escala de abundância dos minerais

Os primeiros pesquisadores no assunto se 1 imitaram a organi zar tabelas de ordem de abundância dos minerais usando termos descritivos, tais como predominante, raro, abundante, etc. Outros estabeleceram esca Zas de abundância arranjando os termos descritivos e escalas numëricas em sequência de crescente raridade ou abundância (Boswelz, 1923 e Mi.lner, 1962). Evans, Hayman e Majeed (1933) usaram uma sērie de nūmeros de fre quência que fornece uma relação logarītmica à frequência real dada pela contagem. Modificadas essas vārias escalas, ē aqui sugerida uma escala de abundância arranjando os termos descritivos em relação a porcentagem real, como ē mostrado a seguir:

Termos

Porcentagem

U1tra predominante

40-80

Predominante

$20-40$

Muito Abundante

Abundante

$10-20$

Muito freqüente

$5-10$

Freqüente

$3-5$

Escasso

$2-3$

Escasso

$1-2$

Muito escasso

$0,5-1$

Raro

Traço

$0,25-0,5$

$<0,25$

Durante o presente trabalho fez-se uso desta classificação. 


\section{ANALISE MINERALOGICA}

Este trabalho não pretendeu reallzar estudos exaustivos de minerais pesados e leves, incluĩndo fragmentos de rocha encontrados nos arenitos amostrados, por serem eles por demais conhecidos. Em alguns ca sos não foi identificada a espécie, apenas o grupo ou famīilia. Por outro lado, as freqüências, caracterīsticas mineralögicas e feições morfoscōpi cas dos minerais pesados e leves dos arenitos nas formações Itararē e Aqui dauana são discutidas totalmente, nas outras formações são descritas somen te as freqüencias, as feições morfoscōpicas dos minerais e parcialmente suas caracterīsticas mineralógicas. Fotomicrografias dos minerais pesados não são apresentadas, pois Coimbra (1976) mostra fotomicrografias detalha das de minerais pesados na Formaçăo Bauru.

\subsection{Formações Itararē e Aquidauana}

\subsubsection{Descrição dos minerais pesados}

Os minerais pesados das formações Itararë e Aquidauana săo: zircão, turmalina, rutilo, granada, apatita, estaurolita, monazita, muscovi ta, cianita, epidoto, titanita, magnetita e ilmanita, leucoxēnio e limoni ta. A tabela II mostra o conteüdo em minerais pesados em porcentagem me dia nos arenitos e em alguns siltitos pertencentes às duas formações; $\overline{0}$ arredondamento e o häbito cristalino dos minerais, e o peso desses mine rais em arenitos.

A descrição mineralögica, ordenada por estabilidade minera Tögica, $\overline{\mathrm{e}}$ a seguinte:

Zircão - Mineral abundante a muito abundante nas duas formações; aprè senta-se incolor e raramente pürpura, marrom e rosa; grãos dominantemente bem arredondados a arredondados e subordinadamente subangulares a subarredondados, comumente globulares, elippticos e alongados; os grãos euēdricos e subëdricos são comuns, com ou sem zoneamento; muitos grãos contēm inclusões orientadas ou năo, sôlidas ou flü̃das; por vezes mostram mar 
Tabela II

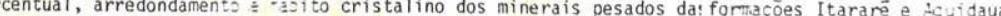

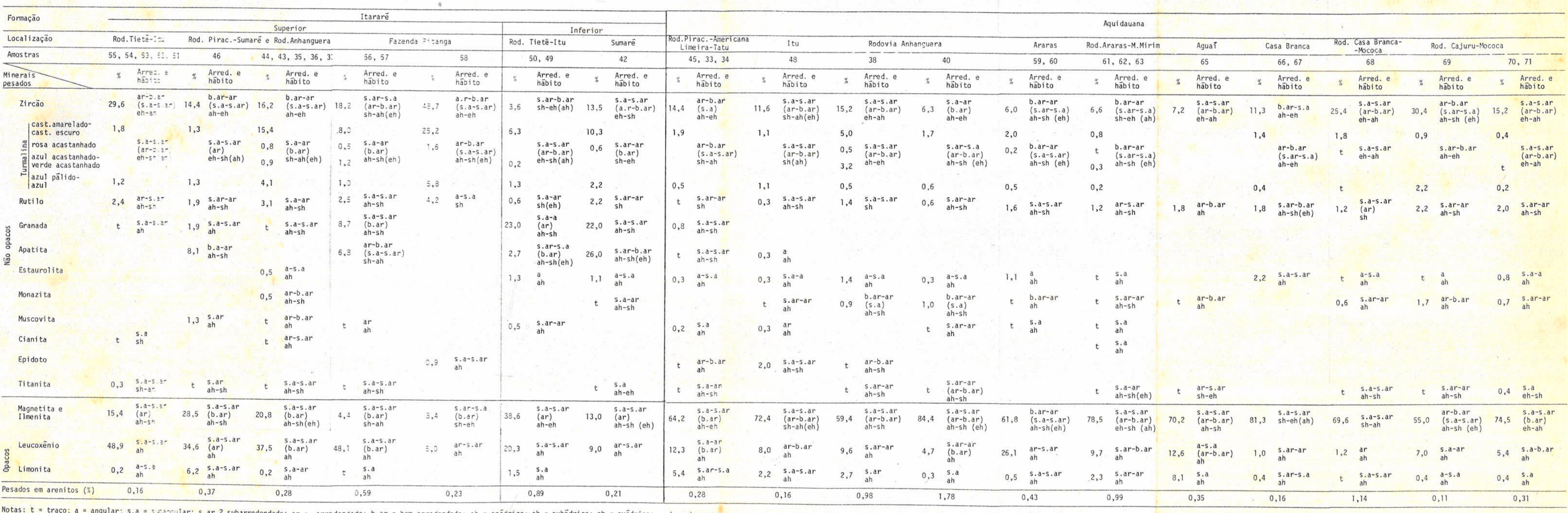


cas de corrosăo.

Turmalina - Em geral, ē um constituinte frequente a muito abundante na Formação Itararē e traço a escasso na Formação Aquidauana;ba seado na cor, seus grãos podem ser divididos em quatro varie dades: castanho-amarelada a castanho-escura, rosa-acastanhada, azul - verde acastanhada e azul a azul-pälida; turmalina ca $\underline{s}$ tanho-amarelada a castanho-escura e dominante em todas as 10 calidades amostradas destas formaçōes e a azul a azul-pālida è comum; as outras variedades, cuja soma ë baixa, estão pre sentes em algumas amostras; os grãos são subangulares a su barredondados e subordinadamente arredondados, com formas fragmentadas, prismāticas e poucas ovaladas; säo cristais com raras inclusões esparsas de pontos opacos ou bolhas e lame las incolores; alguns grãos mostram fraturamento serrilhado e marcas de corrosão.

Rutilo - Constituinte raro a frequente; sua cor $\bar{e}$ vermelha com bordas escuras; ocorre com formas alongadas e equidimensionais, su bangulares a subarredondados; exibe por vezes formas prismä ticas com terminações piramidais, grãos serrithados e gemina ções em joelho, com ou sem estrias longitudinais e obliquüas.

Granada - Componente muito variado, abundante a muito abundante em al gumas amostras da Formação Itararē e traço ou ausente em ou tras; os grãos são subangulares a subarredondados, marcados por fratura conchoidal e padrões superficiais retangulares e reticulado (dissoluçäo superficial); são dominantemente in colores ou rosa, raramente mostrando cores marrom-rosadas é marrom-esverdeadas; inclusões são escassas.

Apatita - Outro componente variāve1, frequlente a abundante em algumas amostras da Formação Itararē e traço ou ausente em outras ; suas inclusões orientadas, sinal de alongamento, bi-refrigên cia baixa, etc., permitem sua räpida identificação: os grãos são dominantemente arredondados a bem arredondados, anēdricos a subēdricos, raramente subangulares e euēdricos. 
cor $\vec{e}$ amare1o-pälida a amarelo-ouro; os grãos são angulares e subangulares, marcados por fratura subconchoidal: alguns gräos mostram fraturamento serrithado altamente caracterīsti co; as inclusões são numerosas.

Monazita - Mineral traço a muito escasso em todas as amostras; apresen ta-se dominantemente arredondado atē esfërico, com cor amare la e alto relevo.

Muscovita - Em geral, ē um mineral traço a muito escasso; seus grãos são tabulares, angulares e arredondados, caracterizados pelo rele vo baixo, cor de interferēncia cinza-esverdeada e figura bia xial negativa.

Cianita - Constituinte traço, ocorrendo somente em poucas amostras;seus grãos são incolores, alongados, marcados por figuras retangu lares controladas pela clivagem.

Epidoto - Mineral traço a raro nos arenitos estudados, os grãos são su bangulares a bem arredondados, sempre em tonalidades verdeamareladas, pleocröicas; as vezes apresenta-se a variedade rosa-amarronzada (zoisita).

Titanita - Mineral traço em todas as amostras; seus gräos são incolores e marrom-amarelados, subangulares a arredondados, equidimensio nais ou ovalados; gräos euēdricos em forma adamantina, são as vezes encontrados; muitos grãos não chegam a mostrar extin ção completa em luz branca devido à alta dispersão.

Magnetita e ilmenita - Minerais opacos abundante a predominante nas duas formações; relativamente, sua quantidade na Formação Aquidaua na ē maior que na Formação Itararē; a maioria dos grãos săo subarredondados a subangulares, com häbito cristalino anēdrị co, subëdrico e euëdrico; os grãos arredondados a bem arredon dados são raros; normalmente a magnetita aparece incrustada por limonita, sendo identificada por sua forma cristalina e a ilmenita contëm manchas de leucoxênio; no caso de grãos arre dondados $\bar{e}$ difícil distinguir a ilmenita da magnetita. 
Leucoxēnio - Mineral predominante na Formaçāo Itararē e muito freqüente na Formação Aquidauana; os grãos são agregados microcristali nos, brancos a branco-amarronzados em luz refletida, subangu lares a arredondados; em algumas amostras da Formação Itara $\vec{e}$, altera-se para anatäsio que possui formas cristalinas euëdricas e subëdricas com tamanhos variāveis.

Limonita - Traço a muito frequente nas duas Formações; äpresenta gräos subangulares a arredondados, marrom a vermelho-amarronzados em Tuz refletida.

4.1.2. Descrição dos minerais leves

Os arenitos das formações Itararē e Aquidauana, de um modo geral, são friāveis mostrando granulometria variāvel, com cores acinzen tadas na Formação Itararē e avermelhadas na Formaçäo Aquidauana. Os compo nentes principais dos arenitos são quartzo, feldspato e fragmentos de ro chas. A matriz ē dominantemente argilo-micācea e clorītica, com quanti dade considerāvel de silte em ambas unidades estratigräficas. 0 cimento é ferruginoso com menor quantidade de calcita e sillica. 0 tamanho médio, seleção, arredondamento, maturidade textural, maturidade mineralögica e nome das rochas säo apresentados na tabela III. A descrição ē a seguinte:

Quartzo - E o ultra predominante componente mineralōgico dos arenitos, muitas vezes apresentando inīcio de corrosão e superfïcies concavas ou serrithadas, as vezes substituĩdo por sericita ou calcita; recrescimento secundārio ao longo de um nūcleo de quartzo ē escasso; tambēm è comum a deposição de uma fina película de oxido-hidröxidos de ferro que faz parte do mate rial cimentante das rochas; segundo as inclusões e extin ções e outras caracterĩsticas, o quartzo foi classificado em trēs variedades, descritas a seguir em ordem de abundāncia:

a. quartzo comum - contendo poucos vacüolos e microlitos, ex tinção aproximadamente reta ou levemente ondulante e for ma aproximadamente equidimensional. 


\begin{tabular}{|c|c|c|c|c|c|c|c|c|c|c|c|c|c|c|}
\hline \multirow{3}{*}{ Localização } & \multirow{3}{*}{$\begin{array}{l}\text { Anios } \\
\text { tras }\end{array}$} & \multirow{3}{*}{$\begin{array}{l}\text { Tamanhos } \\
\text { dos gräos }\end{array}$} & \multirow{3}{*}{$\begin{array}{l}\text { Sele } \\
\text { çào }\end{array}$} & \multirow{3}{*}{$\begin{array}{l}\text { Arredon } \\
\text { damento }\end{array}$} & \multirow{3}{*}{$\begin{array}{c}\text { Maturidade } \\
\text { textural }\end{array}$} & \multicolumn{7}{|c|}{ Composiçào mineralögica } & \multirow{3}{*}{$\begin{array}{l}\text { BAT. } \\
\text { MIN. } \\
\vdots\end{array}$} & \multirow{3}{*}{$\begin{array}{c}\text { Nome das } \\
\text { rochas }\end{array}$} \\
\hline & & & & & & \multirow{2}{*}{ Quart } & \multirow{2}{*}{$\begin{array}{l}\text { Felds } \\
\text { pato- }\end{array}$} & \multicolumn{2}{|c|}{$F R$} & \multirow[t]{2}{*}{ Mica } & \multirow{2}{*}{ Matriz } & \multirow{2}{*}{ Cimento } & & \\
\hline & & & & & & & & $S$ & $R$ & & & & & \\
\hline Rod.Tieté-itu & 54 & med. -mf. & $r$ & sa-sar-ar & $S \mathrm{Sm}$ & 88 & 12 & - & - & tr. a & $\arg$ & $\mathrm{fe}$ & 88 & subarcōsio \\
\hline Rod.Tieté-itu & 52 & g. -med. & mà & sa-sar-ar & imat & 80 & 25 & $-t$ & $\operatorname{tr}$ & tr. a & arg. & $\mathrm{fe}$ & 80 & subarcösio \\
\hline Rod.Tieté-itu & 51 & f. $-m . f$. & $r$ & sa-sar & $5 m$ & 81 & 18 & - & - & $1 a$ & arg. & $\mathrm{fe}$ & 81 & subarcōsio \\
\hline Rod.Tieté-Itu & 50 & g. -m.f. & $m \bar{a}$ & sa-sar & imat & 70 & 27 & 1 & 2 & $-s$ & st.arg. & cal.fe & 71 & arcósio \\
\hline Itu & $48 *$ & m.f.-st. & $r$ & $a-s a$ & $\mathrm{sm}$ & 87 & 11 & tr. & - & 2 & arg. & fe.si & 87 & subarcösịo \\
\hline \multicolumn{2}{|c|}{ Rod. Americ.-Pirac. 46} & m.f.-st. & $r$ & $s a-a$ & $\mathrm{sm}$ & 89 & 10 & - & - & 1 & arg. & $\mathrm{fe}$ & 89 & subarcósio \\
\hline \multirow{2}{*}{\multicolumn{2}{|c|}{$\begin{array}{l}\text { Rod. Ane ric. -Pi rac. } 45 * \\
\text { Rod. Aneric. - Pi rac. } 44\end{array}$}} & n.f. f. st. & $r-b$ & $a-s a$ & $s m-m a t$ & 92 & 5 & - & - & 3 & $\arg$ & $\mathrm{fe}$ & . 92 & subarcósio \\
\hline & & f.-st. & $r$ & sa-sar & sm mat & 91 & 5 & 1 & - & 3 & arg. & fe.mg & 92 & subarcósio \\
\hline Sumarē & 42 & g. $-5 t$ & mà & a-sa-sar & imat & 73 & 22 & 3 & 1 & 1 & st.arg. & fe.si & 76 & subarcósio \\
\hline Tatu & 35 & f. $-m f$ & $r$ & sarsar & $\mathrm{sm}$ & 93 & 4 & 1 & - & 2 & arg. & $\mathrm{fe}$ & 94 & subarcósio \\
\hline Rod. Anhanguera & 36 & med.-m.f. & ถลа & sa-sar & imat & 82 & 16 & 1 & - & 15 & st.arg. & $\mathrm{fe}$ & 83 & subarcösio \\
\hline Rod. Anhanguera & $40^{*}$ & med.-m.f. & $r$ & sa-sar & inat-sm & 89 & 10 & - & - & 15 & st.arg. & $f e-s i$ & 89 & suharcósio \\
\hline Campinas & $38^{\star}$ & g. - $f$ & mồ & sa-sar & imat & 95 & 4 & - & 1 & $-s$ & st.arg. & $\mathrm{fe}-\mathrm{si}$ & 97 & quartzoarenito \\
\hline Fazenda Pitanga & 57 & m.g. $-f$ & mà & sa-ar & imat & 71 & 25 & - & 4 & - & st.arg. & $\mathrm{fe}$ & 71 & arcósio \\
\hline Fazenda Pitanga & 58 & g. - f . & $r-b$ & sa-sar-ar & $\mathrm{sm}$ & 81 & 18 & - & - & 1 a & arg. & $\mathrm{fe}$ & 81 & subarcösio \\
\hline Araras & $59 *$ & f. - m. f. & $r-b$ & sa-sar-ar & sm-mat & 98 & 2 & - & - & $\operatorname{tr}$. & arg. & fe.si & 98 & quartzoarenito \\
\hline Rod. Araras-M.Hirim & $1161 *$ & g. $-m . f$. & $m \bar{a}$ & sa-sar & inat & 97 & 2 & - & - & 12 & arg. & fe.si & 97 & quartzoarenito \\
\hline Mogi-Mirim & $63^{\star}$ & $g .-m . f$. & mã & sa-sar & imat & 100 & - & - & - & $-s$ & st.arg. & $\mathrm{fe}$ & 100 & quartzoarenito \\
\hline Aguai & $65^{\star}$ & $g-m . f$. & $m \vec{a}$ & $a-s a r$ & imat & 93 & 5 & I & $i$ & tr. s & st.arg. & $\mathrm{fe}$ & 94 & subarcosio \\
\hline Casa Branca & $67^{*}$ & ned. -1 & 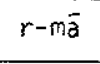 & sa-sar & imat & 100 & - & - & - & $-s$ & st.arg. & $\mathrm{fe}$ & 100 & quartzoarenito \\
\hline Rod.Casa Branca- & $68 a^{\star}$ & g. - med. & $m a \vec{~}$ & $5 a-a$ & imat & 84 & 14 & $2 t$ & $\operatorname{tr}$ & tr: & st.arg. & $\mathrm{fe}$ & 86 & subarcösio \\
\hline -Mococa & $68 \mathrm{~b}^{\star}$ & med.-st. & mä & sa-sar & sm-imat & 83 & 15 & $1 \mathrm{t}$ & $\operatorname{tr}$ & 15 & st.arg. & $\mathrm{fe}$ & 84 & subarcōsio \\
\hline Rod. Cajuru-Mococa & $69^{\star}$ & m.f. & $r$ & sar & $\mathrm{sm}$ & 87 & 11 & 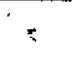 & - & $2 a$ & arg. & $\mathrm{fe}$ & 87 & subarcósio \\
\hline Rod. Cajuru-Mococa & $70^{*}$ & med. & mã & sa-sar & imat & 95 & 2 & $1 \mathrm{t}$ & $\operatorname{tr}$ & 2 & arg. & fe.5i & 96 & Quartzoarenito \\
\hline Rod. Cajuru-Hococa & $71^{*}$ & med. & mā & sa-sar & imat & 90 & 8 & tr. & 1 & 15 & st.arg. & $\mathrm{fe}$ & 90 & subarcōsio \\
\hline
\end{tabular}

Notas: * Amostras da formaçäo Aquidauana; st. = silte: m.f. = muito fino: $f$ = fino: med. = mēdio; g. = grosseiro; th.g. = muito grosseiro; $b=$ boa; $r=$ regular: $a=$ angular; sa $\approx$ subangular: sar = subarredondado; ar = arredondado; imat = imaturo; $\mathrm{sm}=$ submaturo: mat $=$ maturo; $F R=$ fragmentos de rochas; $S=$ shlex: $0=$ outros: - = näo encontrado; tr. = traço; arg. = argila; fe = limonita e/ou hematita; si = silica; MAT.MIN. = maturidade mineralögica; cal. = calcita; mg. = manganita. 
b. quartzo metamörfico - caracterizado por inclusöes mine rais, extinção fortemente ondulante, tanto nos grãos sim ples como nos compostos.

c. quartzo retrabaihado - muito raro, bem arredondado, recrescimento e abrasão.

com

Feldspato - Representados por feldspato potässico, plagioclāsio e fragmen tos de granitos e/ou gnaisses; sua soma, variando de $0-26 \%$, decresce de sudoeste para nordeste da ārea estudada; seu ta manho médio é equivalente ao do quartzo, as vezes maior; con siste geralmente em ortocläsio, microclinnio e plagiociāsio al calino, intemperizados parcialmente e alterados em sericita e caolim, às vezes substituĩdos pela calcita e/ou sericita.

Fragmentos de rochas - Traço a muito freqüente nos arenitos, inclui frag mentos de rochas metamörficas, como xistos e filitos, e ro chas sedimentares, como silex e poucos arenitos muito finos; os gräos de silex säo subangulosos a arredondados, tambëm mos trando feições de corrosão.

Mica - Os grandes fragmentos (> 20 micra) são principalmente de mus covita, biotita e alguma clorita, concentrados nos arenitos finos a muito finos; as formas são angulosas, alongadas, ãs vezes curvadas.

Cimento - Consiste predominantemente de limonita e/ou hematita, com pou ca calcita, sïlica e manganita; preenche parcialmente ou leve mente os vazios entre os gräos maiores; argilo-minerais re cristalizados atravēs de processos diagenēticos servem tambëm como cimento.

Matriz - Em geral supera 5\%, sendo constituîda por argilo-minerais e silte; os minerais de argila são principalmente micāceos e clorïticos; grăos detrïticos e microcristalinos de origem diagenëtica são igualmente encontrados, estes üttimos consti tuĩdos por uma mistura de värios minerais de argila. 
mação Itararē, situados no sudoeste da ārea estudada, săo classificados principalmente como subarcōsios a arcōsios e os da Formação Aquidauana, no nordeste da ārea estudada, como quartzoarenitos e subarcōsios (tabela III).

\subsubsection{Variações mineralögicas}

As suites dos minerais pesados das formações Itararē e Aqui dauana na ārea estudada são muito variāveis, tanto vertical como lateral mente, como mostrado na tabela II. Suas variações mais notāveis são as se guintes:

\section{Formação Itararēe:}

0 zircão è um mineral dominantemente arredondado a bem arre dondado, cuja quantidade è maior no pacote superior da Formação Itararē que em seu pacote inferior. Turmalinas são principalmente subangulares a arredondados, com maior frequência nas regiões de Piracicaba, Fazenda $\mathrm{Pi}$ tanga, Limeira e Sumaré, tanto no pacote superior como inferior da unidade. A distribuição de rutilo ê mais ou menos homogênea.

Os minerais meta-estāveis, granada e apatita, são encontra dos no topo do pacote superior da Formação, nas proximidades de Piracicaba e Fazenda Pitanga e os minerais granada, apatita e estaurolita são encon trados no pacote inferior, nas proximidades de Porto Feliz e Sumarē. Os grãos de apatita säo arredondados a bem arredondados, os de granada são subangulares a subarredondados, e os de estaurolita angulares. 0 epidoto, subangular a subarredondado, somente aparece na Fazenda Pitanga.

Os minerais opacos são subangulares a subarredondados e seus häbitos cristalinos são anëdricos a euēdricos, no caso da magnetita e ane drico, no caso do leucoxênio e da limonita. A quantidade de leucoxênio $\overline{\bar{e}}$ predominantemente maior que a de magnetita e ilmenita no pacote superior e menor no pacote inferior da Formação.

Formação Aquidauana: 
formação. Sua distribuição ē variāvel, concentrando-se nas regiões de Ca sa Branca, Mococa e onde as formações Aquidauana e Itararē são interdigita das. Turmalina e rutilo são minerais subangulares a bem arredondados. ocorrem em pequena quantidade e espalhados homogeneamente nas regiões es tudadas.

Os minerais meta-estāveis, estaurolita e monazita, apresen tam-se em quantidades consideräveis em quase todas as localidades. Nas re giões de Itu, Campinas e Tatu, aparece epidoto arredondado a bem arredonda do.

Os minerais opacos são principalmente subangulares a subar redondados e subordinadamente arredondados. Magnetita e ilmenita predomi nam em todas as amostras desta Formação, sendo a quantidade de leucoxênio relativamente baixa. A limonita, cuja quantidade $\overrightarrow{\mathrm{e}}$ maior que na Formação Itararê, $\vec{e}$ frequente em quase todas as amostras.

\subsection{Formaçäo Piramböia}

4.2.1. Descrição dos minerais pesados

Os minerais pesados da Formação Piramböia são: zircão, tur malina, rutilo, granada, estaurolita, muscovita, cianita, epidoto, bioti ta, sillimanita, magnetita e ilmenita, hematita e limonita. A tabela IV mostra o conteüdo percentual em minerais pesados presente nos arenitos des ta Formação, o arredondamento e o häbito cristalino e peso desses minerais nos arenitos. As caracteristicas mineralögicas foram anteriormente des critas para as formações Itararē e Aquidauana(P.15). As frequências e feções morfoscöpicas dos minerais pesados são as seguintes:

Zircão - Constituinte muito escasso dos minerais pesados não opacos, mas abundante na amostra 29 , chegando a $11 \%$, seus grãos prin cipalmente incolores säo bem desgastados, comumente alongados, elïpticos e globulares; os grãos euëdricos ou subēdricos são raros,com ou sem zoneamento; as variedades pūrpura e marrom as vezes estão presentes.

Turmalina - Constituinte freqüente a abundante nesta Formação; seus grãos 
Composiçào percentual, arredondamento e häbito cristalino dos minerais pesados da Formaçào piramböia

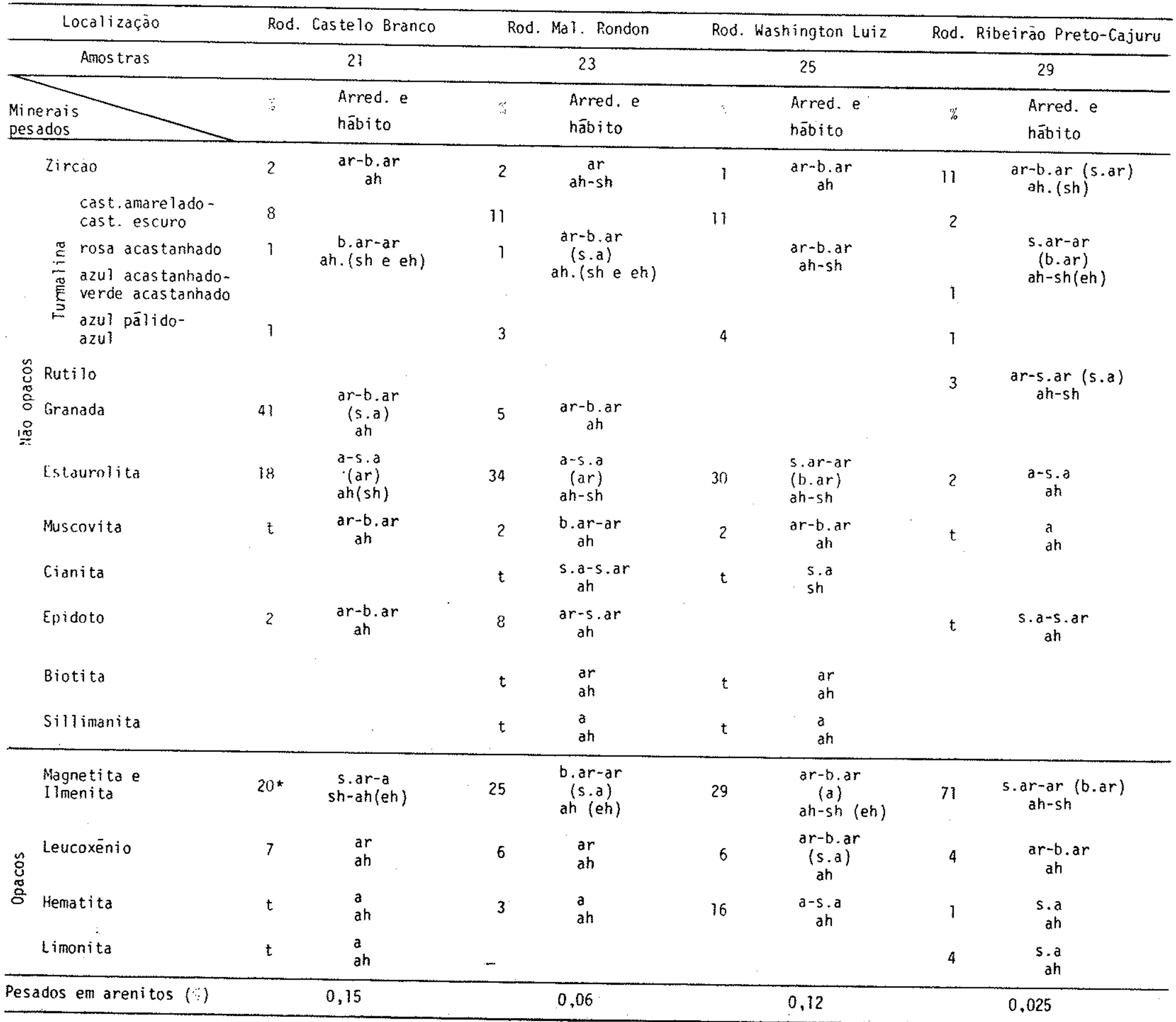

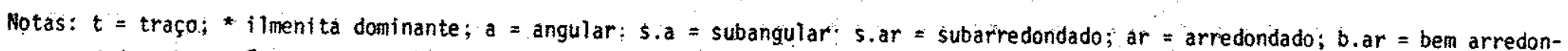
dado; ah = anédrica: $s h=$ subêdrico; ef = euêdricico: $(\ldots)=$ pouco. 
podem ser divididos em quatro variedades como nas formações Itarare e Aquidauana; turmalinas castanho-amareladas a casta nho-escuras são abundantes na maioria das localidades amostra das desta formaçăo, enquanto as outras variedades aparecem em porcentagem muito baixa; os grãos são arredondados a bem arre dondados, equidimensionais ou ovalados e a forma prismätica ca è rara.

Rutilo - Constituinte acidental, aparecendo somente na amostra 29; os grãos são arredondados a bem arredondados, anēdricos a subë dricos.

Granada - Componente muito variado nesta Formação chegando a atingir 5 e $41 \%$ nas amostras 23 e 21 , respectivamente; as granadas in colores e em parte as variedades rosa e marrom, arredondadas a bem arredondadas, săo encontradas nesta Formação.

Estaurolita - Constituinte muito abundante no conjunto dos näo opacos, mas escasso na amostra 29; os grãos são angulares, subangulares e subarredondados a arredondados.

Muscovita - Mineral traço a muito escasso; os grãos são arredondados a bem arredondados e anëdricos.

Cianita - Constituinte traço; seus grãos são subangulares a subarredon dados e anēdricos a subëdricos.

Epidoto - Mineral encontrado nas amostras 21, 23 e 29, em porcentagem de atē $8 \%$; os grăos são subarredondados a bem arredondados.

Biotita - Constituinte traço; seus grãos são de cor marron, arredondados e anëdricos.

Sillimanita - Constituinte traço; seus grãos são incolores, em pequenos pris mas, marcados por partição longitudinal e estrias paralelas ao comprimento.

Magnetita e Ilmenita - Minerais opacos muito abundantes na maioria das amos 
tras, mas predominantemente na amostra 29; apresentam grãos bem arredondados a arredondados, subangulares a angulares e häbito cristalino anēdrico, subëdrico e euēdrico, respectiva mente; alguns grãos de magnetita foram alterados para hemati ta, com a tendência para a cor vermetha nas bordas; a quanti dade de magnetita de um modo geral e maior que a de ilmenita.

Leucoxēnio - Mineral opaco freqüente a muito freqülente; os grãos são ar redondados a bem arredondados e anëdricos.

Hematita - Mineral opaco, traço a escasso, abundante apenas na amostra 25; os grãos são angulares e arredondados, pretos com bordos ver melhos ou translücidos; partes dos grãos são alteradas a limo nita.

Limonita - Mineral traço a freqüente; apresenta grãos angulares a suban gulares, marrom e preto-amarronzados em luz refletida; ocor rem em agregados pulverulentos e, em parte, cimentando peque nos grãos de quartzo.

\subsubsection{Descrição dos minerais leves}

Os arenitos da Formação Pirambōia de um modo geral são friä veis, de cores cinza-clara a cinza-amarelada e vermelha a vermelho- acasta nhada, de granulometria fina a mëdia, dominantemente. Os componentes prin cipais dos arenitos são quartzo, feldspato, fragmentos das rochas, cimento e matriz. Seu tamanho mëdio, arredondamento, grau de seleção, maturidade e nome das rochas são apresentados na tabela $V$. A descrição ë a seguinte:

Quartzo - Ultra predominante componente mineralögico dos arenitos; mui tas vezes apresenta com sinais de recrescimento, exibindo, em seus contornos, sîlica cristalina precipitada com a mesma or $\underline{i}$ entação ötica do mineral; tambëm è comum a deposição de uma fina pelīcula de coloração vermelha na superfĩcie dos grãos, constituĩda de öxido-hidroxidos de ferro que algumas vezes faz parte do material cimentante da rocha; foi classificado em três variedades principais: quartzo comum, quartzo meta 
Tabe la $V$

Composição mineralögica e caracterĩsticas texturais dos arenitos da Formação Pirambōia

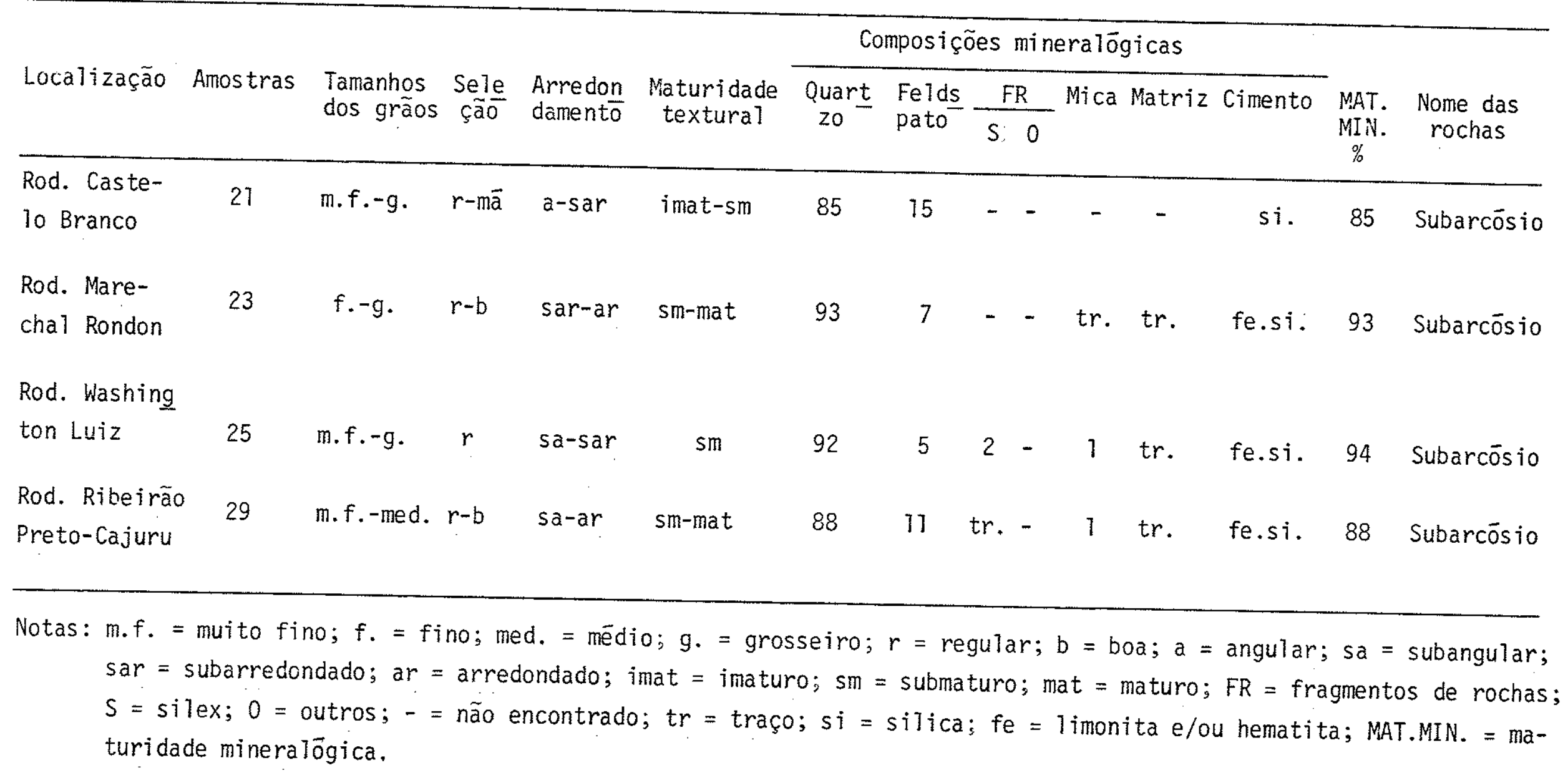


mörfica e quartzo retrabalhado.

Feldspato - Constituinte muito freqliente a abundante, cujo tamanho $\bar{e}$ me nor que o do quartzo; consiste geralmente em ortocläsio, mi croclinnio e plagiocläsios alcalinos, intemperizados parcialmen te e alterados a caolim e/ou sericita.

Fragmentos de rochas - Particulas finas a mëdias, bem arredondadas, prin cipalmente silex; suas quantidades săo traço a escasso.

Mica - Principalmente representada pela muscovita e sericita, em quan tidade menor que $1 \%$.

Cimento - Consiste predominantemente de sîlica recristalizada (quartzo microcristalino) e pouca limonita e/ou hematita na superfí cie dos grãos; a sillica preenche parcialmente os vazios en tre os grãos.

Matriz - Encontra-se apenas traço de matriz sỉitica.

Segundo a classificaçäo de Folk (1968), os arenitos da For mação Pirambōia são classificados como subarcōsio.

\subsubsection{Variações Mineralōgicas}

0 estudo detalhado da suite de minerais pesados da Formação Piramböia mostrou algumas variações na distribuição horizontal na faixa de afloramentcs (tabela IV).

Os minerais ultra-estāveis, como zircão e turmalina, são do minantemente arredondados a bem arredondados. Suas distribuições são simi lares nas regiões da Rodovia Castelo Branco, Rodovia Marechal Rondon e Rodovia Washington Luiz (parte sudoeste), mas com alta freqüēncia de zir cão e presença de rutilo na Rodovia Ribeirão Preto - Cajuru (parte nordes te), sendo porëm baixa a frequencia de turmalina.

os minerais meta-estāveis näo opacos, como granada, estauro lita, muscovita, cianita, epidoto e biotita, são angulares a bem arredon 
dados, concentrados na parte sudoeste. Sillimanita, instāvel e angular ē tambëm presente na parte sudoeste.

Os minerais opacos, como magnetita e ilmenita, leucoxēnio, hematita e limonita säo angulares a bem arredondados. 0 conteūdo de mag netita e ilmenita aumenta de sudoeste para nordeste e de leucoxēnio dimi nuiu. A quantidade relativa de hematita decresce da parte central para am bos os lados, enquanto a de limonita se concentra na parte nordeste.

\subsection{Formação Botucatu}

\subsubsection{Descriçăo dos minerais pesados}

Os minerais pesados encontrados na Formação Botucatu são os mesmos da Formação Piramböia. A tabeila VI apresenta o conteūdo percen tual em minerais pesados nos arenitos, o arredondamento e häbito cristali no e o peso desses minerais em arenitos. As caracterīsticas mineralögi cas foram descritas nas formações Itararē e Aquidauana (p.15) e Piramböia (p.23). As frequências e feições morfoscōpicas dos minerais pesados são as seguintes:

Zircão - Constituinte traço a freqüente; os grãos são bem arredonda dos a arredondados e dominantemente anēdricos.

Turmalina - Constituinte escasso a muito abundante, variando de 2 a 28\%; os grãos são bem arredondados e arredondados, equidimencionais ou ovalados e raramente prismäticos.

Rutilo - Constituinte traço, aparecendo somente na amostra 27;0s grãos são angulosos, prismāticos, com ou sem estriações oblīquas.

Granada - Componente traço a escasso; os grãos são quase incolores, an gulares a subangulares e anëdricos a subëdricos.

Estaurolita - Constituinte traço a muito abundante; sua quantidade atinge $27 \%$ e sua freqüencia ë bastante variävel de uma amostra para outra; os grãos são angulares a arredondados, anëdricos e 
Conposiçao percentual, arredondanento e häbito cristalino dos minerais pesados da Fornaçao Botucatu

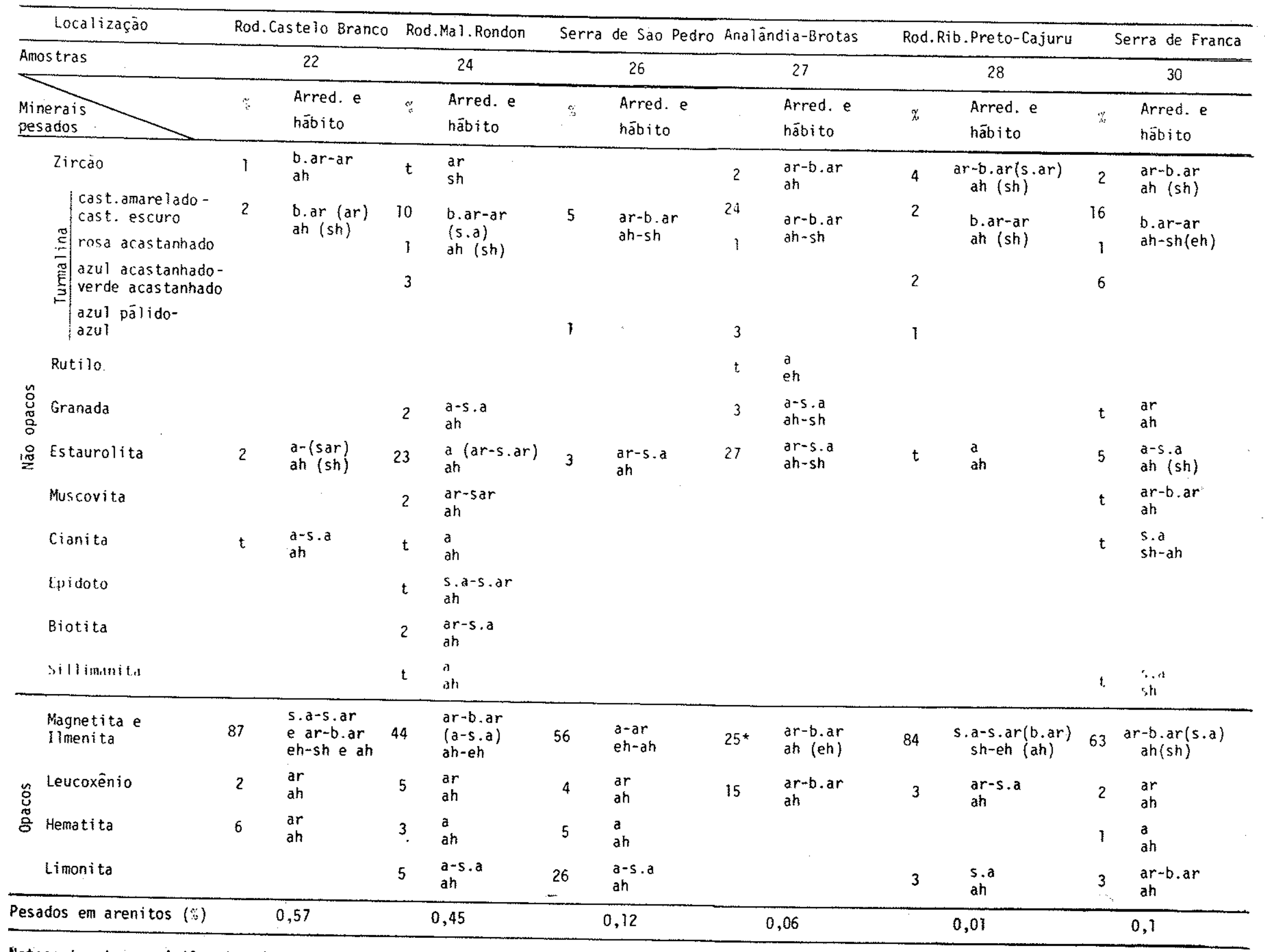

Notas: $t=$ traço; * imenita dominante; $a=$ angular; $5 . a=$ subangutar: $s . a r=$ subarredondado; ar $=$ arredondado; $b . a r=b e m$ arredondado: ah $=$ ane

drico; sh = subếdrico; eh = quëdrico; $(\ldots)=$ pouco. 
raramente subëdricos.

Muscovita - Mineral traço a muito escasso; seus gräos são arredondados a subarredondados.

Cianita - Mineral traço; seus grãos são alongados, angulares a suban gulares e anëdricos a subëdricos.

Epidoto - Mineral somente encontrado na amostra 24; os grãos são suban gulares a subarredondados.

Biotita - Mineral muito escasso, apenas aparecendo na amostra 24; os grãos são arredondados a subangulares.

Sillimanita - Mineral traço e somente aparece na amostra 24; seus grãos são alongados e angulares.

Magnetita e Ilmenita - Minerais opacos muito abundantes a predominantes.va riando de 25 a‡e $87 \%$; os grãos são subangulares a subarredon dados e euēdricos a subēdricos nas amostras 22,26 e $28, \bar{e}$ arredondados a bem arredondados, anëdricos, nas outras amos tras.

Leucoxênio - Mineral escasso a abundante entre os opacos, variando entre 2 - 15\%; os gräos são arredondados a bem arredondados e anedricos.

Hematita - Mineral traço a muito freqüente; os grãos säo angulares e arredondados e anēdricos.

Limonita - Mineral traço a freqüente, sendo abundante na amostra 26 ; apre senta grãos arredondados a bem arredondados na amostra $30 \mathrm{e}$ angulares a subangulares nas outras. 
Devido à similaridade entre os arenitos da Formação Botuca tu e Formação Pirambōia, torna-se difícil distinguir um do outro pelas ca racterísticas litolögicas observadas no campo. De acordo com exame mi croscöpico, as caracterīsticas dos arenitos da Formação Botucatu estão re sumidas na tabela VII:

1. As características dos grãos minerais de quartzo, feldspato e fragmen tos da rocha são iguais às dos arenitos da Formação Piramböia.

2. A distribuição granulomētrica dos arenitos, em geral, ē bimodal nas fra ções de areia mëdia a grosseira e muito fina a fina.

3. Os grãos são dominantemente arredondados a bem arredondados na fração grosseira, e subangulares a arredondados na fração fina.

4. O feldspato è um componente traço a muito frequlente, ocorrendo em menor quantidade que nos arenitos da Formação Piramböia.

5. 0 cimento consiste de limonita e/ou hematita nas superfícies dos grãos e não è encontrada matriz.

Segundo a classificação de Folk (1968), os arenitos de For mação Botucatu são classificados principalmente como quartzo-arenito e subordinadamente como subarcōsio.

\subsubsection{Variações mineralōgicas}

A suite dos minerais pesados da Formação Botucatu mostrou variações na distribuição horizontal na faixa de afloramento (tabela VI). os minerais ultra-estāveis, como zircão e turmalina, são bem arredondados a arredondados. As turmalinas apresentam altas freqüen cias nas amostras coletadas nas Rodovias Marechal Rondon e Analândia - Bro tas e na Serra de Franca, e baixas freqüencias nas Rodovias Castelo Bran co e Ribeirão Preto - Cajuru e na Serra de São Pedro; o zircão ē raro a freqüente, distribuído na maioria das localidades de coleta.

os minerais meta-estāveis não opacos como granada, estauro lita, muscovita, cianita, epidoto, biotita e sillimanita são angulares a 
Tabela VII

Composição mineralögica e características texturais dos arenitos da Formação Botucatu

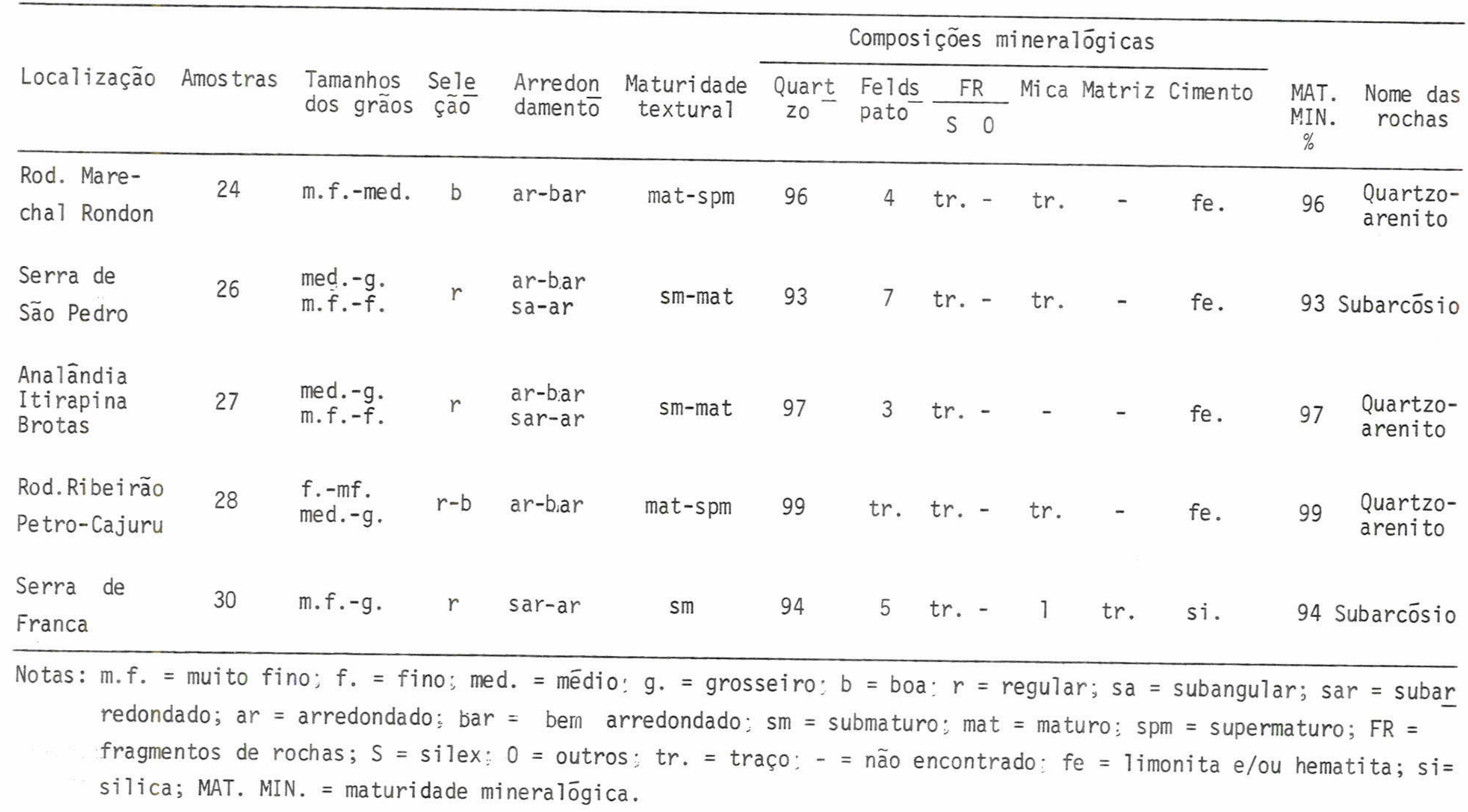


arredondados. A estaurolita se concentra nas āreas das Rodovias Marechal Rondon e Analāndia - Brotas amostradas. Outros minerais são acidentais. Os minerais opacos como magnetita e ilmenita, leucoxēnio

hematita e limonita são angulares a bem arredondados. As freqüencias de magnetita e ilmenita são bem elevadas na maioria das localidades exceto nas Rodovias Marechal Rondon e Analāndia - Brotas. A quantidade de leucoxênio $\overline{\mathrm{e}}$ escassa a muito freqüente na maioria das regiōes, mas abundante na Rodo via Analändia - Brotas. A hematita e a limonita são acidentais.

\subsection{Formação Bauru}

\subsubsection{Descrição dos minerais pesados}

Os minerais pesados da Formação Bauru são zircão, turmalina, rutilo, granada, apatita, estaurolita, monazita, muscovita, cianita, epido to, biotita, titanita, perowskita, anfibölio, piroxênio, sillimanita, mag netita e ilmenita, leucoxēnio, hematita e limonita. A tabela VIII mostra a composição percentual dos minerais pesados nos arenitos da Formaçäo Bau ru, o arredondamento e häbito cristalino dos minerais e o peso dos mesmos em arenitos. As frequéncias e feições morfoscöpicas dos minerais pesados e suas caracterīsticas mineralögicas que não foram descritas nas outras formações, são as seguintes:

Zircão - Mineral raro a muito frequlente na Formação Bauru, variando de 0,7 a $7,0 \%$; ocorre em todas as amostras desta Formação; apre senta-se incolor e mais raramente amarelo-claro, pürpura e ro sa; seus grãos são bem arredondados, com formas globulares, elipticas e alongadas, com ou semzonação; os grãos possuindo häbitos prismäticos simples alongados, terminados ou não em pirāmides, são raros.

Turmalina - Constituinte freqüente a abundante nesta Formação, variando de 2 a 20\%; seus grãos podem ser divididos em quatro variedades; turmalinas castanho-amareladas e castanho-escura säo escas sas a abundantes em quase todas as amostras na Formação Baú ru; as azul-verde acastanhadas são traço a muito escasso; as turmalinas rosa-acastanhadas, geralmente traço em quase toda 
Compos içăo percentual, arredondarento e hăbito cristalino dos minerais pesados da Formação Bauru

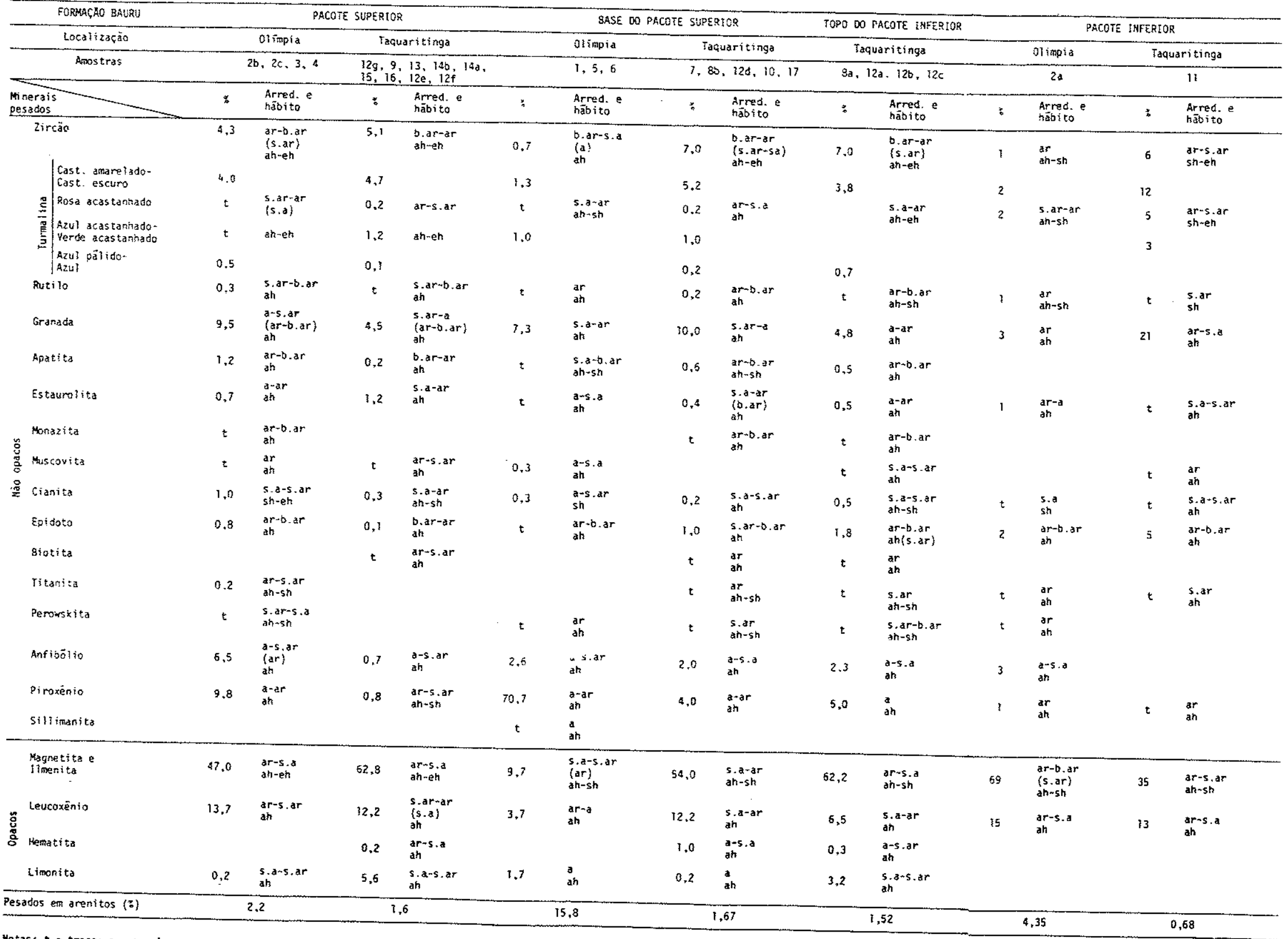

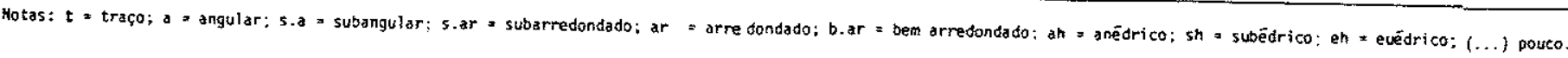


a Formação Bauru ocorre em quantidade apreciāvel em seu paco te inferior; os grãos são subangulares a arredondados, equidimensionais ou ovalados, sendo a forma prismätica subordina da; alguns cristais mostram recrescimento secundārio.

Rutilo - Constituinte traço, aparecendo na maioria das amostras; os grãos são arredondados, ovalados e alongados ou prismäticos, com ou sem estriações oblīquas.

Granada - Componente freqüente a muito abundante em todos os pacotes da Formação Bauru; sua presença varia de 3 a $21 \%$, apresentando-se em geral sem forma cristalina, fraturada, corroĩda e arredon dada; os grãos incolores são dominantes e as cores rosa, mar rom-amarelada e marrom-rosada são raras.

Apatita - Mineral traço a muito escasso; os gräos são arredondados a bem arredondados, sem forma cristalina.

Estaurolita- Componente traço a muito escasso; ocorre em maior quantidade, no pacote superior da Formação Bauru; os grãos são geraimente angulares a subangulares com fratura subconchoidal e os subar redondados e arredondados são raros.

Monazita - Mineral traço; os grãos apresentam-se bem arredondados atē esfëricos.

Muscovita - Mineral traço; seus grãos são tabulares, angulares a arredon dados e anëdricos.

Cianita - Constituinte traço a raro; os grãos são subangulares a arre dondados e anëdricos a subëdricos.

Epidoto - Sua quantidade, variando de traço a 5\%, decresce do pacote inferior da Formação Bauru para o pacote superior; os grãos são subarredondados a bem arredondados e anëdricos.

Biotita - Mineral traço, encontrando-se alguns poucos cristais nas amos 
tras estudadas; os grãos são arredondados a subarredondados.

Titanita - Mineral traço; seus grãos são incolores ou de coloração amare lo-clara, subarredondados a arredondados, equidimensionais ou ovalados; apresenta-se comumente em inclusões.

Perowskita - Mineral traço; sua cor ē vermelho-amarelada a vermelho-amar ronzada; são caracterīsticas as formas cübicas, subangulares e arredondadas; normalmente tem comportamento anisōtropo e geminação polissintētica.

Piroxēnio - Componente raro a predominante; sua presença ē muito variävel assumindo valores desde 0,8 a $70,7 \%$; suas cores são principal mente pālido-esverdeada ou amarelada, marrom-amarelada, mar rom-escura e incolor; os gräos são principalmente angulares a subangulares e raramente arredondados, marcado por fratura subconchoidal; alguns gräos mostram fraturamento serrilhado e marcas de corrosăo; a variedade dominante de piroxēnio ē a augita.

Anfibölio - Componente traço a muito freqüente; sua presença $\vec{e}$ bastante variāvel, desde 0 a $6,5 \%$; os grãos são alongados, fibrosos e serrilhados; suas tonalidades são verde-pālida a verde-ama relada e verde - castanha a castanho-esverdeada; a variedade dominante è hornblenda.

Sillimanita - Constituinte traço; ocorrendo somente na base do pacote supe rior da unidade; os grãos são alongados e angulares.

Magnetita e ilmenita - Minerais opacos abundantes a predominantes na Forma ção Bauru; apresentam grãos subangulares a arredondados e subordinadamente bem arredondados e angulares e häbitos cris talinos subëdricos, anëdricos e euëdricos, respectivamente, a quantidade de magnetita de um modo geral ē maior que a de ilmenita.

Leucoxênio - Mineral freqülente a abundante entre os opacos; os grãos são subangulares a arredondados e anëdricos. 
Hematita - Mineral traço a raro, encontrando-se poucos grãos no pacote superior e topo do pacote inferior da Formação Bauru na re gião de Taquaritinga; os grãos são angulares a subarredon dados, parcialmente alterados a limonita.

Limonita - Mineral traço a muito freqüente no pacote superior e topo do pacote inferior da Formação Bauru; apresenta grãos angulares a subarredondados, marrom e vermelho-amarronzados em luz re fletida.

4.4.2. Variações mineralōgicas

As suites de minerais pesados nas äreas de 0limpia e Taqua ritinga mostram variações importantes, tanto vertical como lateralmente. Como mostrado na tabela VIII, suas características são as seguintes:

1. No pacote superior da Formação Bauru:

Os minerais ultra-estāveis como zircão, turmalina e ruti 10 são subarredondados a bem arredondados e suas variações em ārea não são notāveis. Granada, apatita, epidoto, titanita e perowskita tem major fre qüência na região de 0 ỉmpia em relação a Taquaritinga e seus valores de arredondamento são baixos a altos. Piroxēnio e anfibōlio, instāveis, an gulosos a arredondados, são muito freqüentes na região de 01 împia e raros na região de Taquaritinga. Em geral, seus valores de arredondamento são mais altos na região de Taquaritinga. Os opacos como magnetita e ilmenita e limonita são assinalados com maior freqüencia na região de Taquaritinga.

2. Na parte basal do pacote superior da Formação Bauru:

Os minerais ultra-estāveis e meta-estāveis como zircão, tur malina, rutilo, granada, apatita, estaurolita, titanita e epidoto são mais abundantes na região de Taquaritinga que 017 ímpia, normalmente seus valo res de arredondamento sendo mais altos na região de Taquaritinga. Os 
grãos de piroxēnio, angulosos a arredondados, instāveis, são significativa mente abundantes chegando a $70,7 \%$ na região de $01 \bar{m}$ mpia. Por causa da maior freqüência de piroxēnio, a quantidade relativa dos opacos naquela região è menor.

3. No topo do pacote inferior da Formação Bauru:

As amostras foram coletadas somente na região de Taquaritin ga. Os arredondamentos e quantidades dos minerais pesados săo similares aos da parte basal do pacote superior. Os minerais como turmalina, ruti 10, granada, apatita, anfibōlio, leucoxênio e hematita são menores e os outros minerais são maiores ou iguais em quantidade comparados com aqueles da parte basal do pacote superior.

4. No pacote inferior da Formação Bauru:

Somente duas amostras foram coletadas e estudadas, de for ma que seus resultados não são suficientes para fins estatîsticos. Todavia, tra-estāveis e meta-estäveis, arredondados, como zircão, turmalina, grana da e epidoto, possuem maior frequência na região de Taquaritinga, e os minerais meta-estāveis arredondados e instāveis angulares, como magnetita e iTmenita, piroxēnio e anfibōitio, são menos freqüentes. 


\section{PROVINCIAS MINERALOGICAS}

Provincia mineralögica ou petrolögica sedimentar $\overline{\mathrm{e}}$ definida como um grupo de sedimentos que constitui uma unidade natural em termos de idade, origem e distribuição (Baturin, 1931 e Edezman, 1933). Este grupo de sedimentos $\overline{\mathrm{e}}$ um corpo tridimencional, caracterizado normalmente por as sociação mineralögica distintiva. E sob essa definição que neste trabalho - termo "provĩncia mineralōgica" serā empregado.

Os resultados obtidos foram colocados em um diagrama ternā rio, em cujas vërtices estão representados os minerais pesados: a)ultra-es tāveis, b) opacos e c) meta estäveis e instāveis. Estes trēs grupos mine rais foram escolhidos por possuirem as maiores freqüencias e representarem proveniências adequadamente.

Os minerais opacos são geralmente considerados um incômodo pelos petrōlogos sedimentares, sendo quase sempre rejeitados na anälise mineralögica, apesar de constituirem comumente a grande maioria dos pesa dos nas rochas sedimentares e serem üteis para as determinações de sua pro veniência. Neste trabalho, os minerais opacos foram estudados e divididos em quatro categorias: magnetita e ilmenita, leucoxēnio, hematita e limoni ta.

Os minerais ultra-estāveis são zircão, turmalina e rutilo; - terceiro vertice $\overrightarrow{\mathrm{e}}$ ocupado por outros minerais incluindo minerais metaestāveis e instāveis como as espēcies mostradas na seção 6.1.

Baseado nos dados da tabela IX foram montadas as figuras 2,4 e 6 , onde cada ponto representa uma amostra definida pelas três varia veis consideradas, ou seja, pesados ultra-estāveis, opacos e outros pesa dos definindo, desse modo, pela posição no diagrama, as värias provincias mineralögicas das formações estudadas.

Escolhidas como "datuns" três superfícies bem caracteristi cas, ou seja, o contato dos sedimentos com rochas cristalinas, o topo da Formação Botucatu e a base da Formação Bauru e as espessuras desses paco tes em diferentes localidades (Andrade e Soares, 1971, Soares e Landim, 1973 e 1975 e Landim, informação verbal), foi possivel constatar as rela ções entre as diversas provĩncias mineralögicas presentes (figuras 3,5 e 7).

5.1. Formações Itararē e Aquidauana 
Como mostrado nas figuras 2 e 3 podem ser definidas três provincias minera iogicas ( $A, B$ e C) para as formações Itararē e Aquidaua na. Devido à interdigitação de litofäcies destas duas formações, as proviñ cjas mineralōgicas são tambēm interdigitadas.

\subsubsection{Provĩncia A}

A Provincia A apresenta uma assemblēia composta de minerais meta-estäveis, ultra-estäveis e opacos. Caracteriza-se pela alta freqüen cia de minerais meta-estäveis como granada, apatita e estaurolita encon trados no topo do pacote superior da Formação Itararē em regiões como Pira cicaba e Fazenda Pitanga e em seu pacote inferior em regiões como Porto Feliz e Sumaré. Os grãos de apatita são arredondados a bem arredondados, os de granada, subangulares a subarredondados, e os de estaurolita, angu lares a subangulares (tabela II). Esta província apresenta grande nümero de espëcies, em torno de 10 a 13.

\subsubsection{Província $B$}

A Provīncia B contēm principalmente minerais ultra-estāveis e opacos. Caracteriza-se pela alta frequencia de minerais ultra-estāveis como zircão, turmalina e rutilo, situados no pacote superior da Formação Itararē nas proximidades de Tietē, Piracicaba, Fazenda Pitanga, Limeira e Americana e na Formação Aquidauana, na região de Mococa. Os grãos de zir cão são dominantemente arredondados a bem arredondados, os de turmalina e rutilo, subangulares a arredondados. Esta provĩncia apresenta um número variävel de espēcies, ou seja 8 a 12.

\subsubsection{Provĩncia C}

A Província C contēm principalmente minerais opacos e ul tra-estäveis. Caracteriza-se pela alta freqüencia de minerais opacos como magnetita e ilmenita, leucoxênio e limonita encontrados na Formação Aqui 


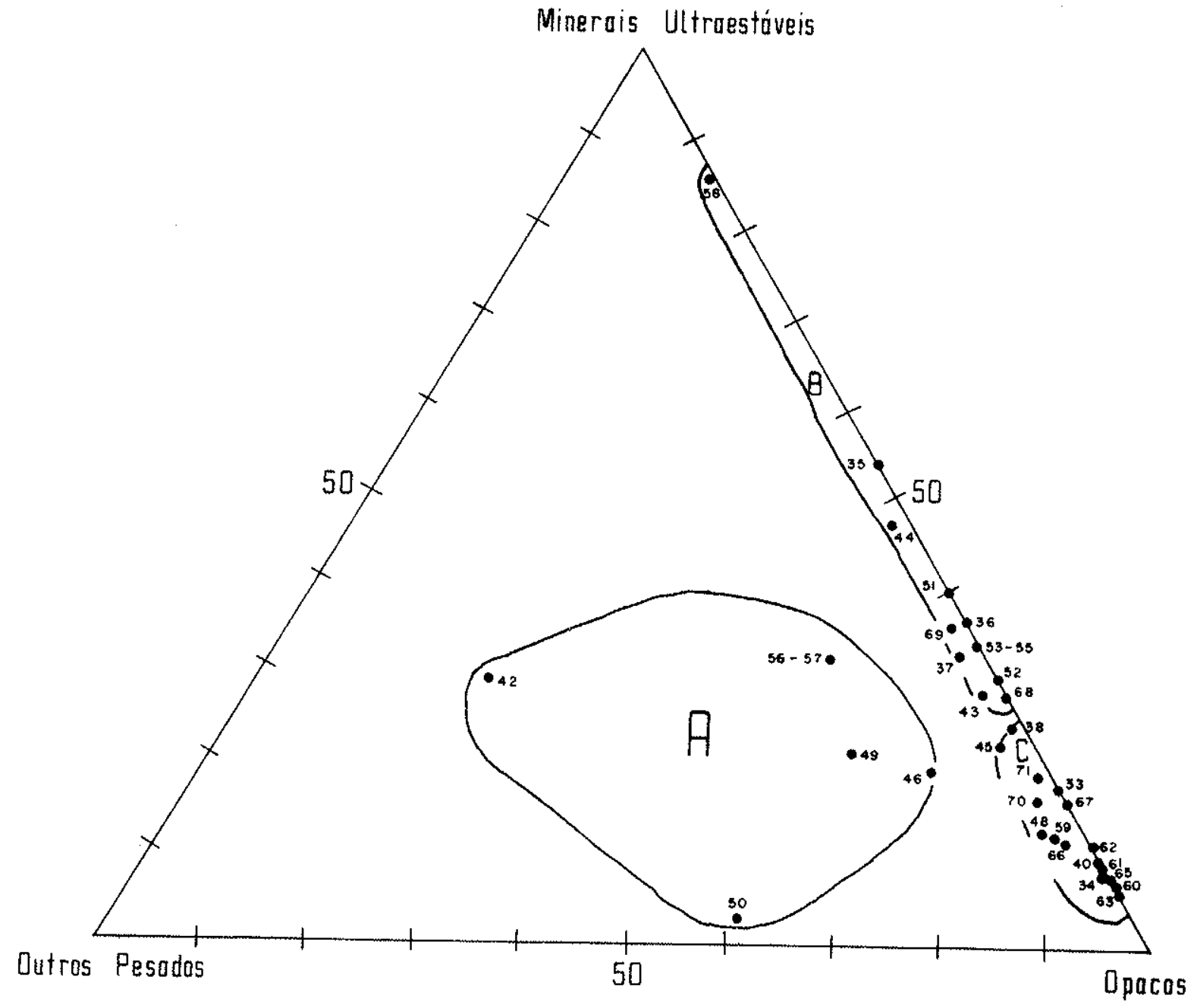

Figura 2- Diagrama triangular delimitondo a distribuiçōo das províncias mineralógicas das formaçōes Itaroré e Aquidauona em funcōo do percentagem de minerais pesados ultraestáveis, apacos e outros. 


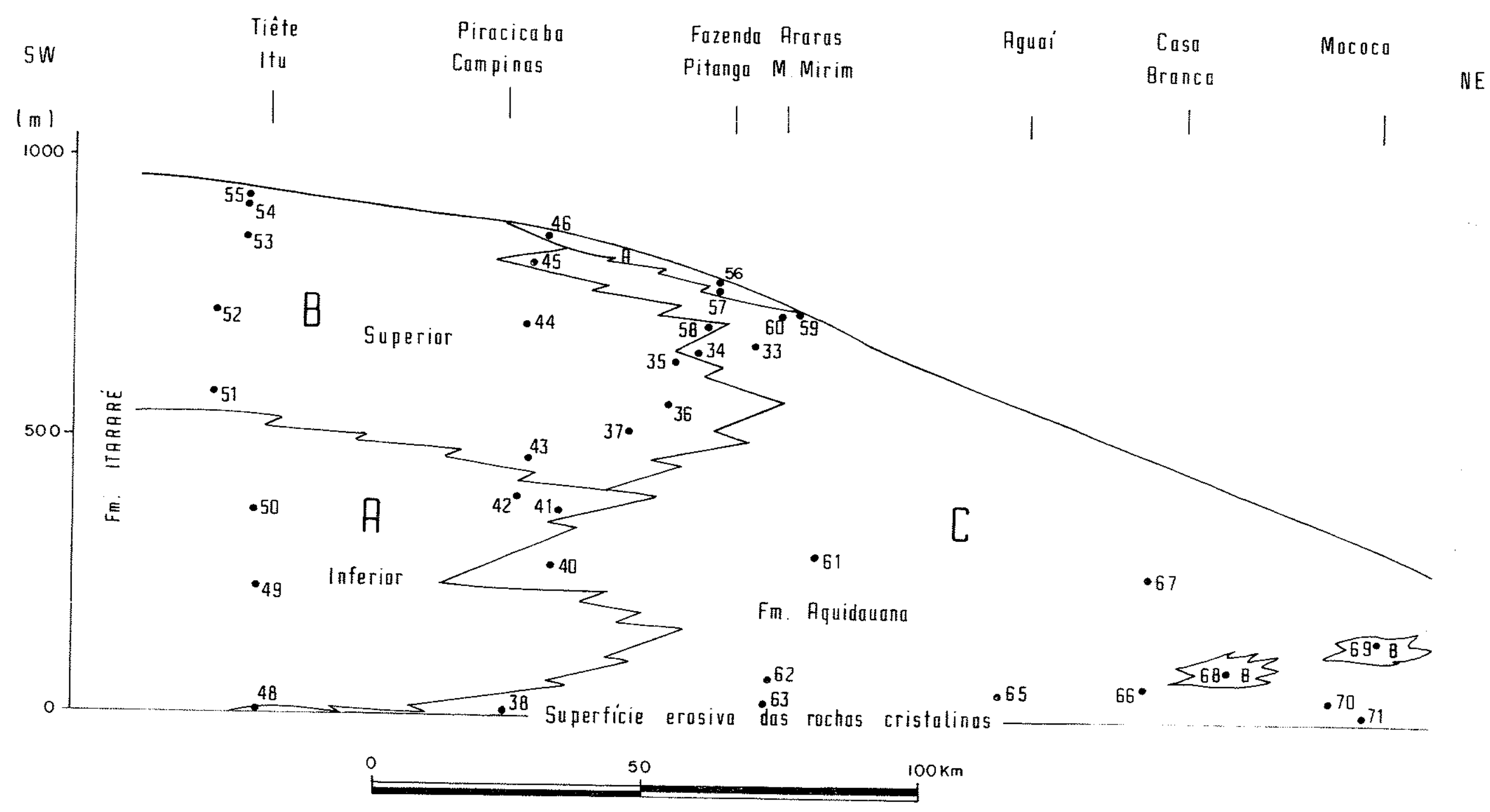

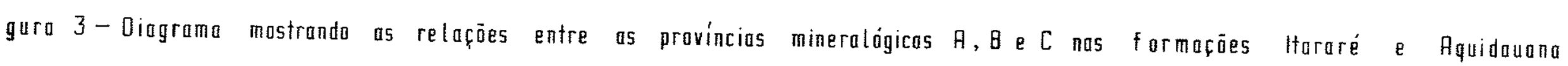


dauana, predominantemente na região nordeste da borda da bacia. A quanti dade de magnetita e ilmenita ē maior que a de leucoxēnio e a limonita é ra ra. Os grãos são principalmente subangulares a subarredondados e subordi nadamente arredondados. Seus häbitos cristalinos säo anëdricos a euëdri cos para magnetita e anēdricos para leucoxênio e limonita. Esta provïncia apresenta nümero de espëcies variäveis tambëm, de 7 a 12 .

\subsection{Formações Pirambōia e Botucatu}

Como mostrado nas figuras 4 e 5 , as provïncias mineralögi cas das formações Pirambōia e Botucatu podem dividir-se em provĩncias A e B. As duas provincias são interdigitadas.

\subsubsection{Provincia A}

A Provincia $A$ apresenta uma assembléia composta de minerais meta-estāveis, opacos e ultra-estāveis. Caracteriza-se pela alta percenta gem de minerais meta-estāveis, como estaurolita, granada, epidoto e mica. A estaurolita, subangular a arredondada, em porcentagem variando entre 18 e 34\%, distribui-se nas āreas amostradas nas Rodovias Castelo Branco e Washington Luiz. Os grãos de granada, epidoto e mica, subangulares a bem arredondados, são concentrados nas äreas das Rodovias Castelo Branco e Ma rechal Rondon. Esta provĩncia apresenta grande nümero de espëcies, em tor no de 9 a 15.

\subsubsection{Provincia $B$}

A Provĩncia $B$ contém predominantemente minerais opacos e se cundariamente minerais ultra-estāveis e meta-estäveis. Caracteriza-se pe la alta porcentagem de minerais opacos como magnetita e ilmenita, leucoxé nio, hematita e limonita encontrados nas äreas compreendida pelas Rodoví as Castelo Branco e Marechal Rondon e concentrados nas regiões de Cajuru e Serra de Franca. Dentre os opacos, magnetita e ilmenita predominam, sen 


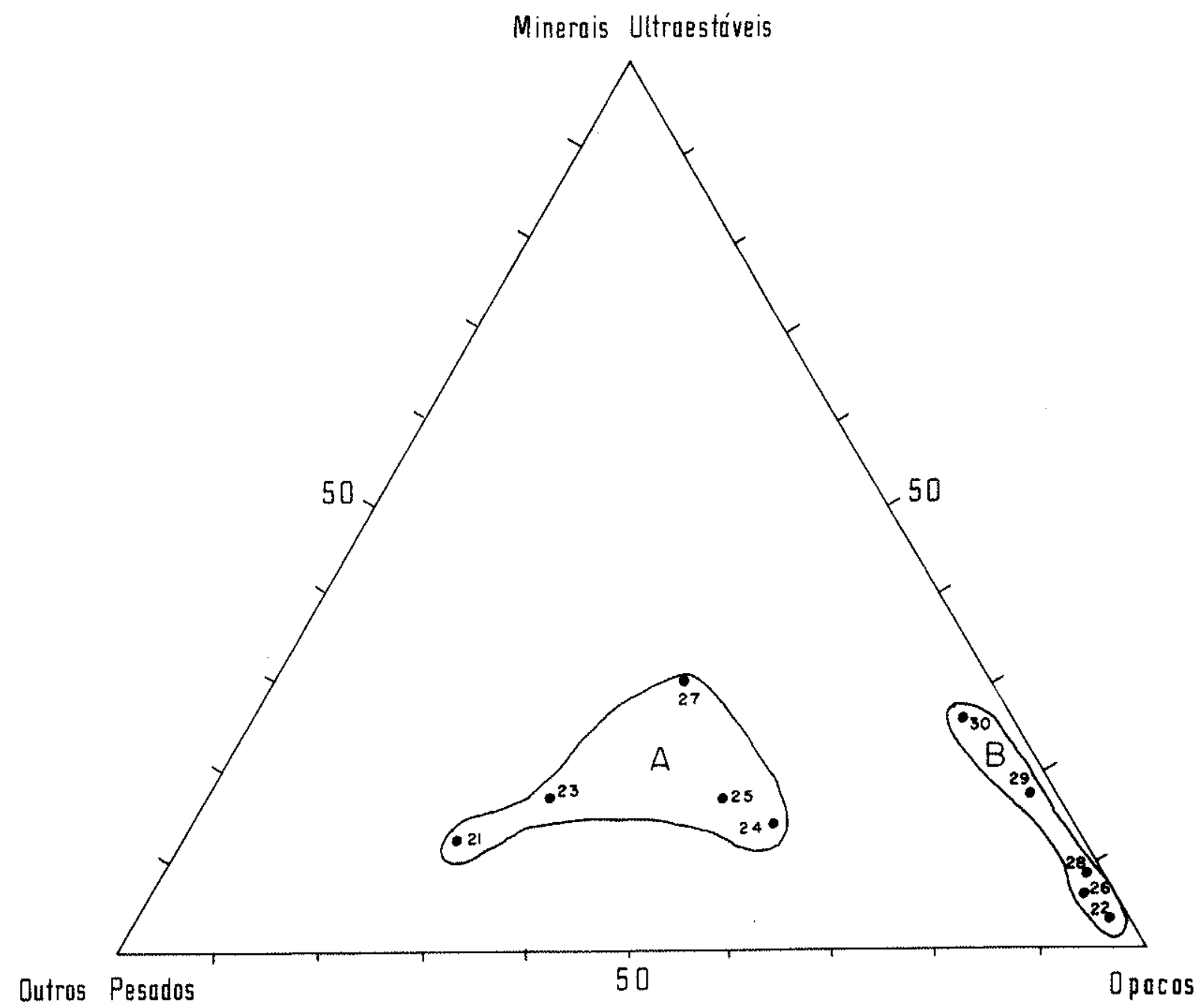

Figura 4 - Diagrama triangular delimitando a distribuiçãa das provincias mineralógicas das formacōes Piramboio e Botucatu em funçāo da percentagem de minerais pesados ultraestáveis, opocos e outros. 


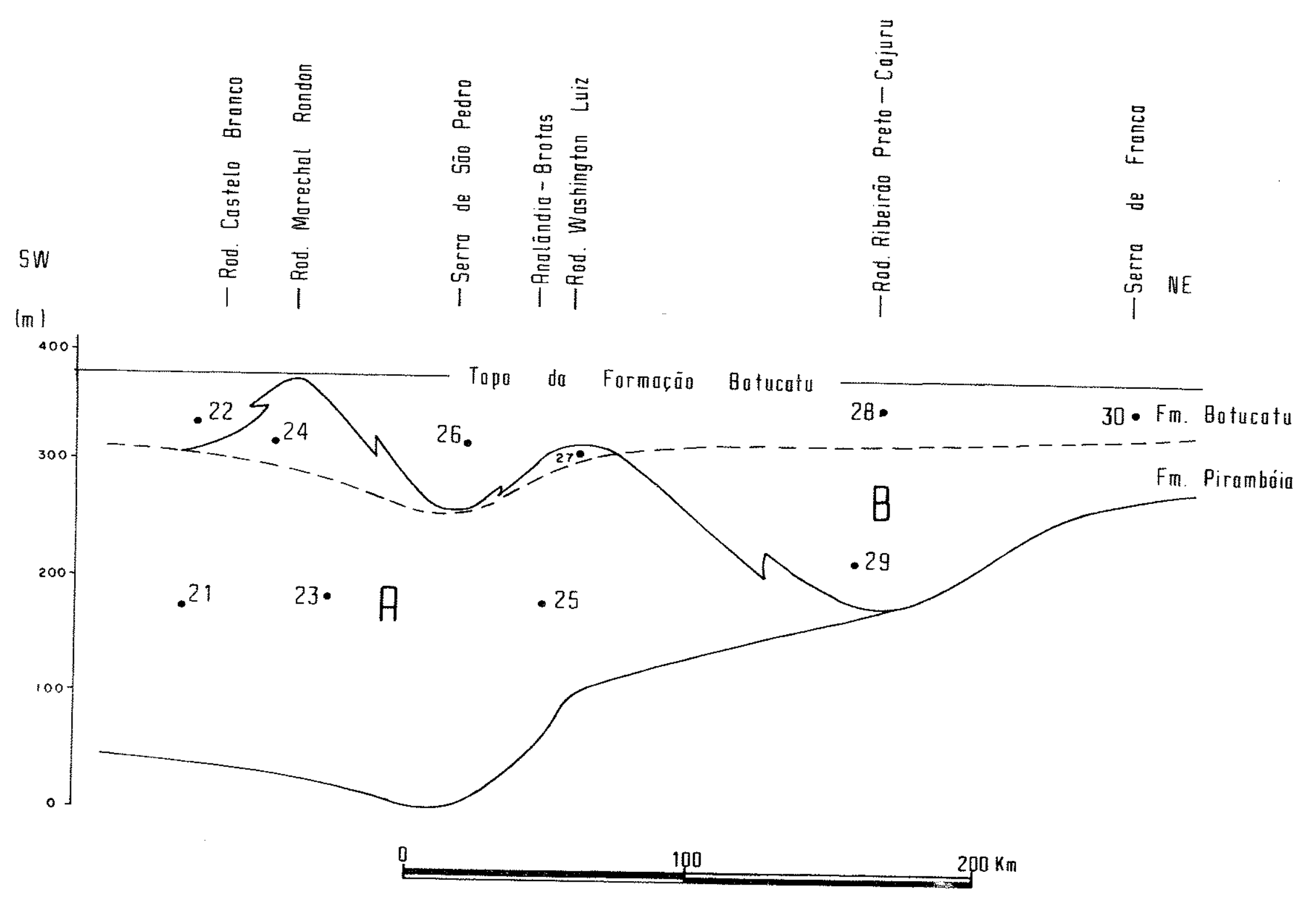

Figura 5-Diagrama mostrando as relaçōes entre as provincias mineralógicas A \& 8 nas formaçōes Pirambóia e Botucatu. 
do os demais subordinados. Apresentam grãos bem arredondados a arredonda dos, subangulares e angulares e häbito cristalino anēdrico, subëdrico e euëdrico, respectivamente. Esta provïncia apresenta nümero de espëcies menor que na Provincia $A$, ou seja, em torno de 7 a 13.

\subsection{Formaçāo Bauru}

Como mostrado nas figuras 6 e 7 , as provincias mineralögi cas da Formação Bauru são divididas em provĩncias $A$ e $B$.

\subsubsection{Provincia $A$}

A Provincia A contēm predominantemente minerais instäveis e meta-estāveis, e secundariamente minerais opacos e ultra-estāveis. Carac teriza-se pelas altas parcentagens de minerais instäveis e meta - estäveis como piroxēnio, granadă, anfibölio e cianita situada dominantemente na ba se do pacote superior da Formação Bauru na região de 0 ïmpia a Santa Adé lia. Os grãos são angulares a arredondados e häbitos cristalinos anēdri cos a subëdricos. Esta provĩncia apresenta grande nümero de espēcies, em torno de 11 a 15.

\subsubsection{Provincia $B$}

A Provĩncia B apresenta uma assemblēia composta e variāvel, mostrando predominância de minerais opacos e secundariamente minerais me ta-estāveis e ultra-estāveis, ocorrendo nos pacotes superior e inferior da Formação Bauru. Os minerais ultra-estāveis como turmalina, zircão e rutilo são dominantemente arredondados; os minerais meta-estāveis como apatita, muscovita, monazita e epidoto são arredondados, e granada, estaurolita,cia nita, magnetita e ilmenita são principalmente subangulares a arredondados; e os minerais instāveis como piroxēnio, anfibōlio e sillimanita são domi nantemente angulares a subangulares, com poucos grãos arredondados. Esta província apresenta nümero de espēcies variāveis, em torno de 7 a 15. 


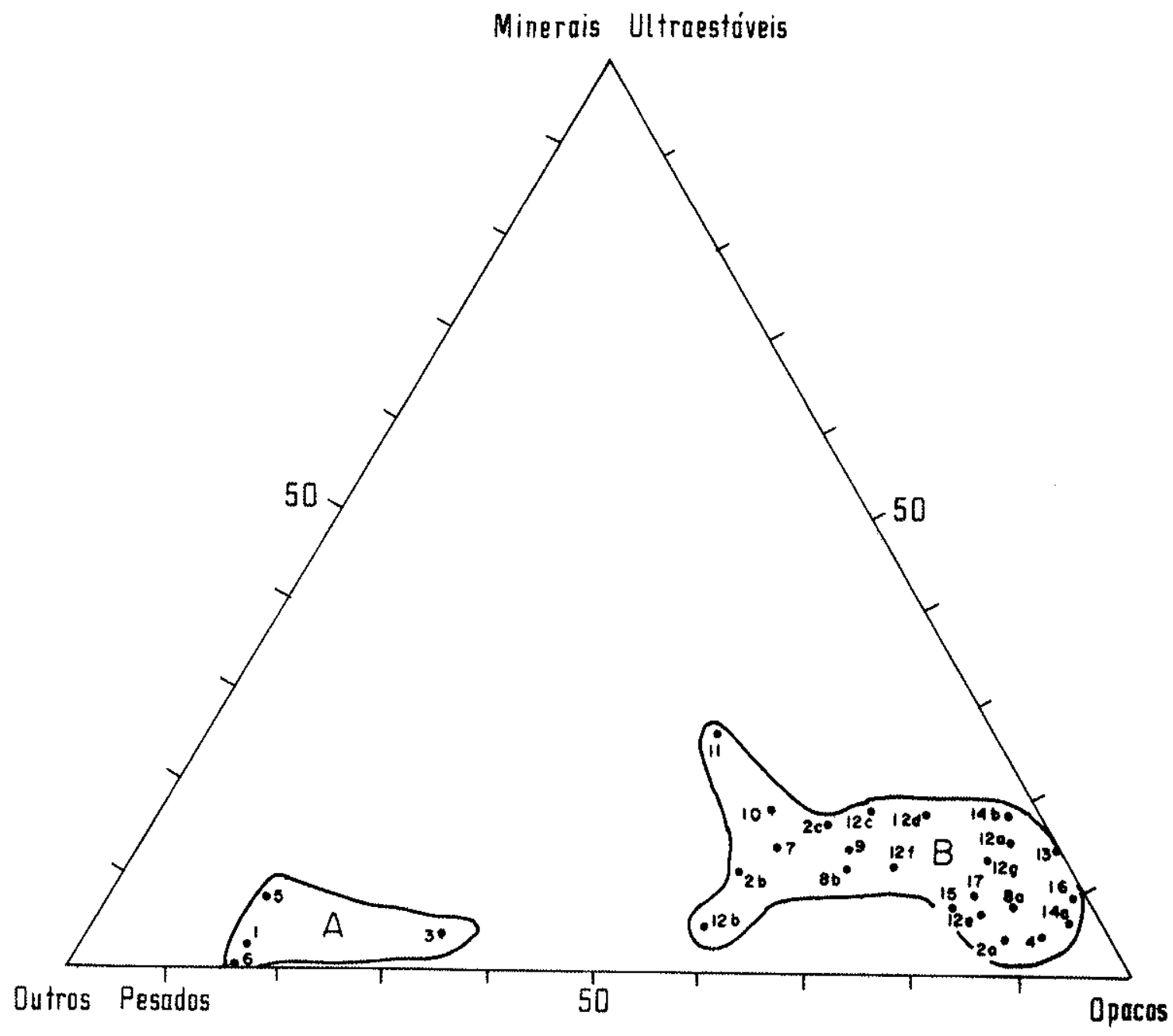

Figura 6 - Diagramo triangular delimitando a distribuicăo das provincias mineralógicas da Formaçōo Bauru em função da percentagem de minerais pesados ultraestáveis, opacos e outros. 


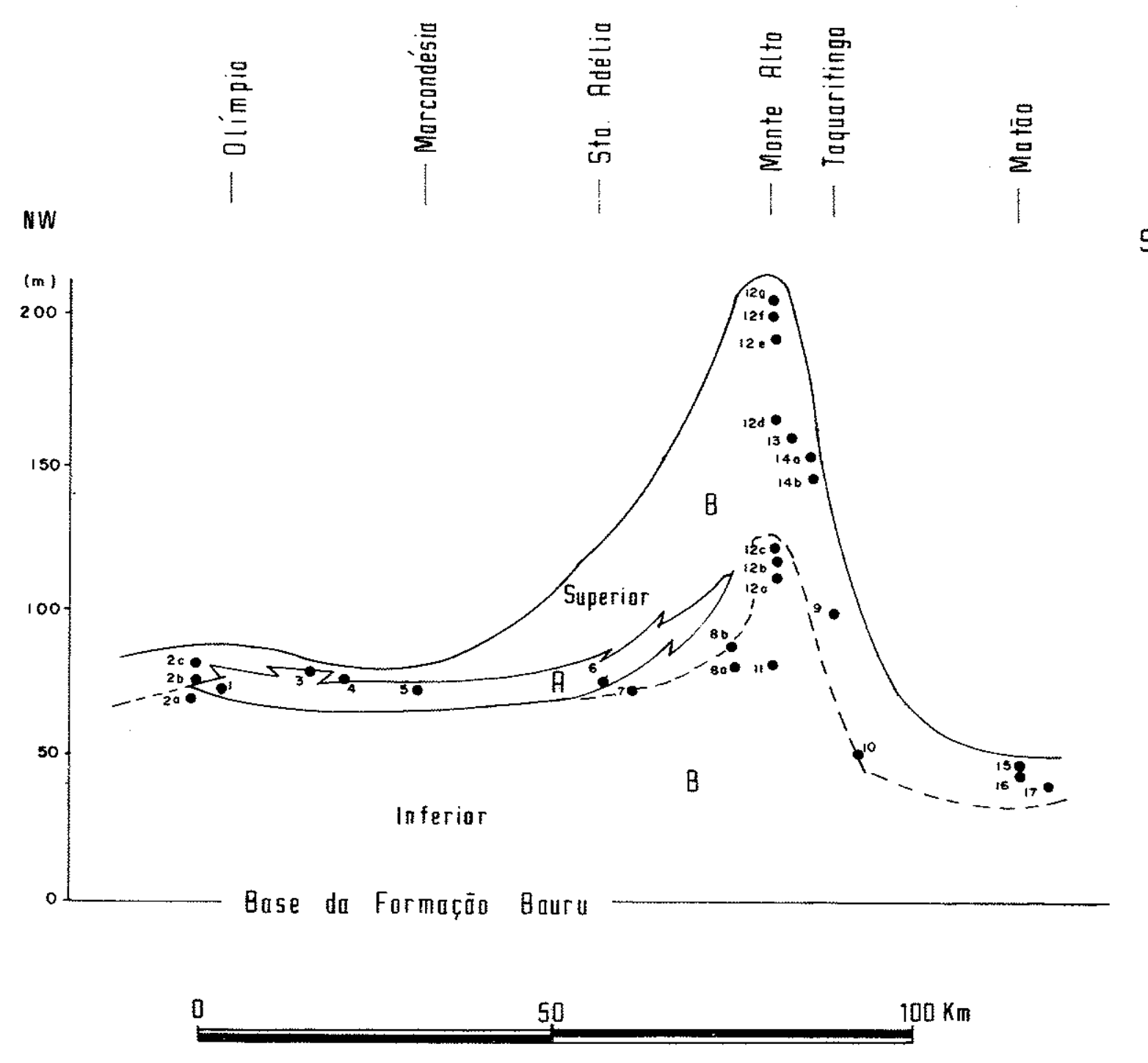

Figura 7 - Diagrama mostrando as relaçōes entre as provincias mineralógicas A e $\theta$ na Formação Bauru 


\section{PROVENIENCI/}

0 termo proveniēncia se refere à rocha-mãe da qual qualquer associação de sedimentos ē derivada. 0 problema da proveniēncia em sedi mentos envolve o conhecimento das composições litolögicas da rocha fonte e de modo idëntico o da natureza do clima e relevo da ārea fonte por meio do estudo da maturidade do sedimento. Assim sendo, neste tipo de anälise torna-se necessārio determinar a estabilidade relativa dos vārios minerais formadores de rochas.

\subsection{Estabilidade mineral}

A estabilidade do mineral refere-se a sua resistēncia à al teração química. Muitos autores estudaram a estabilidade química ou resis tēncia dos minerais à decomposição em perfis de solo e/ou em sedimentos re centes e antigos. Goldich (1938), como um resultado de estudos quantitati vos de alguns perfis de solo, organizou uma sērie de estabilidade de mine rais formadores de rochas, como a seguinte:

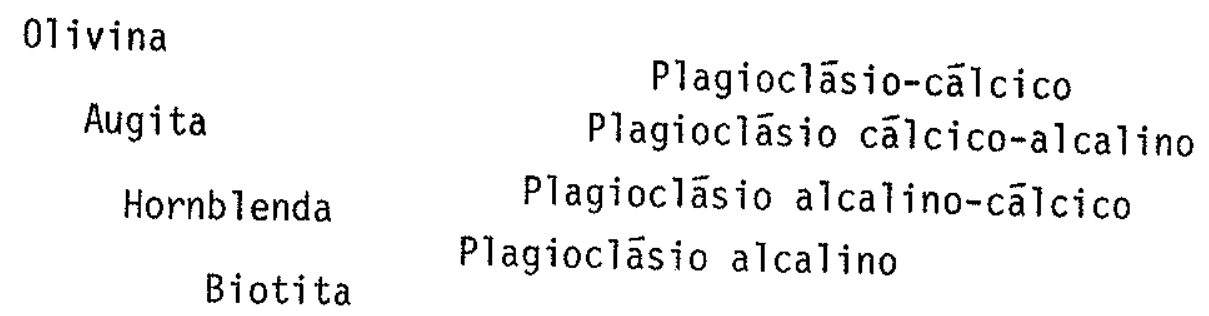

Feldspato potāssico

muscovita

quartzo

E importante salientar que este arranjo não pode ser inter pretado como uma sërie de reaçăo. Assim a olivina não pode alterar-se a piroxēnio este, por sua vez, pode alterar-se a hornblenda, e esta a bio tita. Por outro lado, nas rochas igneas normais a velocidade de decompo- 
sição da olivina excede a do piroxênio, que por seu turno excede a da horn blenda e assim por diante.

A estabilidade de minerais pesados foi estudada por muitos autores, e os mais importantes como Sindowski (1949), Pettijohn (1957), MiIner (1962) e Hubert (1971) são de opinião que o zircão, turmalina e ru tilo são ultra-estäveis e a olivina, piroxênio e anfibōlio são instäveis. Outros minerais mais comuns encontrados neste trabalho como granada, apati ta, estaurolita, monazita, muscovita, cianita, epidoto, biotita, titanita, perowskita, magnetita e ilmenita, leucoxênio, hematita e limonita são clas sificados como minerais estāveis e/ou meta-estāveis, dependendo do autor. Apatita, por exemplo, aparentemente $\bar{e}$ instāvel no solo, mas è estāvel em sedimentos antigos; igualmente os feldspatos alcalinos decompõem-se facil mente no solo, mas podem ser submetidos a crescimento diagnëtico nas ro chas sedimentares (Pettijohn, 1957).

Baseado nas freqüēncias dos minerais pesados que ocorrem nas formações estudades e modificações nas ordens da escala de persistēncia ou estabilidade mineralögica proposta por vārios autores, ē sugerida neste trabatho a seguinte classificação:

U1 tra-estāveis $\left\{\begin{array}{l}\text { Zircão } \\ \text { Turmalina } \\ \text { Rutilo }\end{array}\right.$

Meta-estäveis $\left\{\begin{array}{l}\text { Granada } \\ \text { Apatita } \\ \text { Estaurolita } \\ \text { Monazita } \\ \text { Muscovita } \\ \text { Cianita } \\ \text { Magnetita } \\ \text { Ilmenita } \\ \text { Leucoxēnio } \\ \text { Hematita } \\ \text { Limonita } \\ \text { Epidoto } \\ \text { Biotita } \\ \text { Titanita } \\ \text { Perowskita }\end{array}\right.$ 
Instāveis $\left\{\begin{array}{l}\text { Hornblenda } \\ \text { Piroxēnio } \\ \text { Sillimanita }\end{array}\right.$

\subsection{Maturidade dos arenitos}

Maturidade de sedimentos clästicos ē a medida de sua aproxi mação com um tipo final estāvel, sendo ocasionada por processos de forma ção atuantes sobre os sedimentos. Maturidade $\overrightarrow{\mathrm{e}}$, portanto, um registro com binado do tempo atravēs do qual os processos genëticos foram efetivos da intensidade de ação desses processos. A maturidade pode ser expressa tanto em termos mineralögicos como em termos texturais.

\subsubsection{Maturidade mineralögica}

0 extremo estävel em areias seria aquele sedimento consti tuĩdo somente por quartzo. Este mineral ē o mineral quĩmica e fisicamente mais estāvel entre os contribuintes principais das rochas plutōnicas, de modo que pode ser acumulado em grandes volumes. A medida da maturidade mineralögica de areias e arenitos pode ser dada, portanto, em termos de seu conteūdo em quartzo (Pettijohn, 1957). Por outro lado, como muitos arenitos tem āreas fontes complexas, o indice de maturidade mineralögica poderia ser representado pela proporção combinada de quartzo, silex e me taquartzito (Hubert, 1962). Tal indice de maturidade mineralögica de are nitos $\vec{e}$, inclusive, o mais adequado para este trabalho. Os quatro esta gios de maturidade mineralōgica, propostos aquī, são os seguintes: 1. ima turo (indices $<75 \%$ ); 2. submaturo (indices entre 75 e $85 \%$ ); 3. maturo (indices entre 85 e 95\%) e 4 . supermaturo (indices $>95 \%$ ).

Os indices de maturidade mineralögica nos arenitos das for mações Itararē e Aquidauana são menores que $71 \%$ em arcōsio, entre $76 \% \frac{\text { e }}{2}$ $94 \%$ em subarcósio e maior que $96 \%$ em quartzo-arenito (tabela III).

Estes valores, nos arenitos das formações Piramböia e Botu catu, estão entre $85 \%$ e $94 \%$ em subarcósio e maior que $96 \%$ em quartzo-are nito (tabelas $V$ e VII). 


\subsubsection{Maturidade textural}

Baseado no conteüdo de argila, seleção e arredondamento dos arenitos, a maturidade textural è representada por quatro estägios: imatu ro, submaturo, maturo e supermaturo (Fozk, 1968).

Os arenitos das formações Itararē e Aquidauana são, em ge ral, argilosos e ferruginosos, com granulação mais grosseira na Formaçäo Itararē do que na Formação Aquidauana. A seleção ē mã nos arenitos mais grosseiros e regular a boa nos arenitos mais finos. Os grãos são dominan temente subangulares a subarredondados e os angulares e arredondados são raros. Dessa forma, a maturidade textural dos arenitos das formações Ita rarē e Aquidauana ē fortemente controlada pela distribuição granulométri ca dos arenitos. Em geral, os arenitos grosseiros, incluindo tanto quar tzo-arenitos como arcōsios ou subarcōsios, são texturalmente imaturos e os arenitos finos, incluindo quartzo-arenitos e subarcōsios, são textural mente submaturos a maturos (tabela III).

Os arenitos pertencentes à Formação Pirambōia, classifica dos como subarcōsios, são principalmente de granulometria muito fina a me dia, subangulares a arredondados, contendo pouca argila, ferruginosos, com grau de seleção dominantemente regular e texturalmente submaturos a matu ros (tabela $V$ ).

Os arenitos pertencentes à Formaçăo Botucatu, classificados como quartzo-arenito e subarcōsio, são dominantemente finos a mēdios, sem argila, ferruginosos, arredondados a bem arredondados, com grau de seleçäo bom a muito bom e maturidade textural variando de maturo a supermaturo (ta bela VII).

\subsubsection{Maturidade nos vārios arenitos e respectivos controles geolögicos}

Os arcōsios e subarcōsios da Formação Itararē, situados no sudoeste da ārea estudada, são cinza a cinza-claros e cinza-acastanhados, textural e mineralógicamente imaturos a submaturos. Os subarcösios da For mação Aquidauana, localizados no nordeste da ärea estudada, são caracteri zados pela cor vermelha, com quantidade subordinada de feldspato, textural mente submaturos a imaturos e mineralögicamente submaturos com granulação mais fina que os subarcossios da Formação Itararë. Baseado nestas diferen 
ças, pode-se concluir que os arcōsios e subarcōsios da Formação Itararē de vem ter sido derivados dominantemente do Embasamento Cristalino, em ārea de relevo acentuado a moderado, e transportados por meio de alta energia como o gelo, correntes de turbidez e āguas fluviais, e depositados modera da a rapidamente em bacia de subsidência rāpida. Os subarcōsios da Forma ção Aquidauana devem ter sido derivados tambēm principalmente do Embasamen to Cristalino, em ārea de relevo moderado e sob ação de intemperismo mais intenso, tendo sido transportado por meios de energia relativamente mais baixa que os sedimentos da Formaçäo Itararē.

Os quartzo-arenitos mais grosseiros da Formação Aquidauana encontrados em Campinas, Rodovia Araras-Mogi-Mirim, Casa Branca e Rodovia Cajuru-Mococa são vermelhos, mal selecionados, texturalmente imaturos e mi neralōgicamente maturos. Isto significa que os materiais destes quartzoarenitos foram derivados dos quartzitos e rochas graniticas bem intemperi zados existentes no Embasamento, transportados por āguas correntes e rapi damente depositados na borda da mesma bacia.

Os quartzo-arenitos e subarcōsios das formações Aquidauana e Itararē nas regiões entre Americana, Tatu e Araras, onde estas formações apresentam-se interdigitadas, de granulação fina, bem a regularmente sele cionados e texturalmente submaturos a maturos, com baixa quantidade de feldspatos, sugerem que os materiais destes arenitos foram derivados dos sedimentos Itarare e Aquidauana jā depositados e de rochas do Embasamento Cristalino, transportados por meio de energia ainda mais baixa. Alēm disso, estes materiais sofreram ação seletiva mais intensa e processo de retraba Ihamento.

Finalmente, as caracterīsticas de maturidade mineralögica e textural dos subarcōsios da Formação Pirambōia e as dos quartzo-arenitos e subarcōsios da Formação Botucatu indicam que os materiais destes areni tos são os produtos de äreas de relevo pouco acentuado, aqueles em clima semiārido e estes em clima árido. Nestas condições, os materiais dos su barcōsios da Formação Pirambōia sofreram abrasão eōlica apreciāvel na estạ ção de estiagem, tendo sido transportados por āgua corrente na estaçäo chü vosa e depositados em canais fluviais de bacia estāvel.

Os materiais dos quartzo-arenitos e subarcōsios da Formação Botucatu foram carregados inicialmente por correntes fluviais para as par tes marginais ou mais interior da bacia, dependendo da intensidade de chu vas. Posteriormente, tais materiais foram fortemente retrabalhados pelo vento e depositados na mesma bacia, em ambiente desërtico. 
6.3. Maturidade dos minerais pesados transparentes não micāceos

As assemblēias dos minerais pesados de arenitos são, em grân de parte, função das proporções dos vārios minerais pesados erodidos da ärea fonte e da intensidade de modificação dos detritos por abrasão seleti va e seleção hidräulica durante transporte e deposição. Uma vez que a as semblëia dos minerais pesados transparentes não micāceos dos quartzo-are nitos ē composta predominantemente por zircão, turmalina e rutilo, os grãos concentrados em arenitos pela abrasão prolongada e seleção hidräulica são quartzo (incluindo silex e metaquartzito), zircão, turmalina e rutilo. Alëm disso, as composiçōes mineralögicas e texturais de arenitos são interdepen dentes (Krynine, 1948) e teoricamente a composição de minerais pesados trans parentes não micäceos dos arenitos relativamente quartzosos estä correla cionada com a composição de minerais leves e a textura dos arenitos. Por tanto, o indice zircão-turmalina-rutilo, referente a porcentagem combina da de zircão, turmalina e rutilo entre os minerais pesados transparentes, excluindo micas e minerais autigenios, foi proposto como indice (indice ZTR) do grau de modificação de toda a assemblëia dos minerais pesados de arenitos (Hubert, 1962).

0 grau de modificação dos minerais pesados transparentes não micāceos dos arenitos nestas formações estudadas nem sempre se correlacio nam com o de minerais leves e com as texturas dos arenitos, cujos valores são controlados pelas rochas fontes, relevo, clima e meio de transporte. As variações de indice ZTR encontradas entre os arenitos e os possĩveis contro les geolögicos são os seguintes:

1) Nos arcōsios e alguns subarcósios do topo do pacote superior e do paco te inferior da Formação Itararē, dominantemente imaturos textural e mi neralögicamente, os indices ZTR são menores do que $66,9 \%$ (tabelas III IX) e significativamente correlacionäveis às composições dos minerais leves e texturas dos arenitos. Isto significa que estes materiais fo ram dominantemente derivados de rochas granīticas em ārea de relevo acentuado sob clima frio, pouco intemperizados e transportados pelo ge lo ou ãgua de degelo ou correntes de turbidez, e não sofreram ação sele tiva e alteração quĩmica apreciäveis.

2) Nos quartzo-arenitos mais grosseiros da Formação Aquidauana, imaturos texturalmente, os indices ZTR, variando de $74,1 \%$ a $99 \%$ (tabelas III e 
semat w

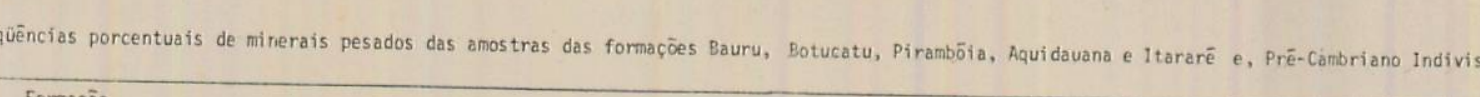

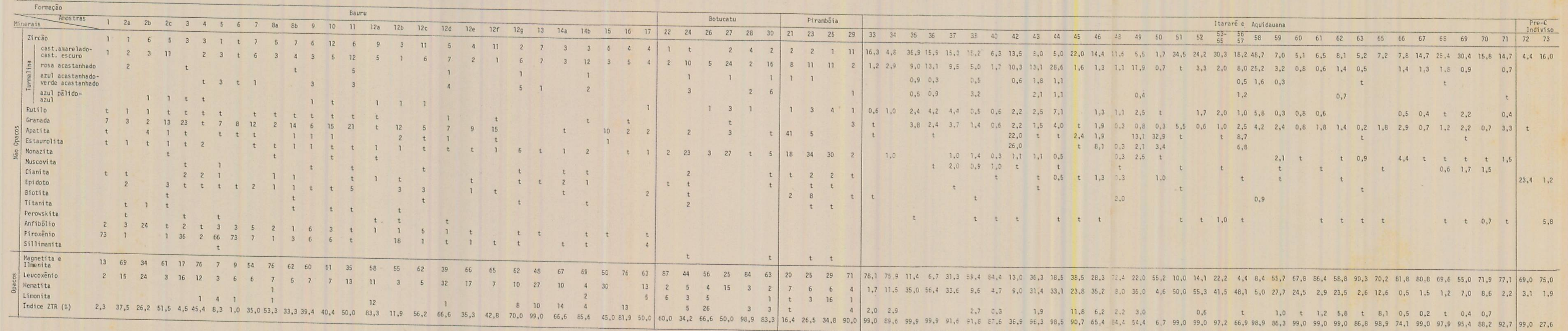


IX), são sempre correlacionados com as composições de minerais leves e não correlacionados com as texturas dos arenitos. Este resultado po de ser explicado da seguinte forma: os minerais instāveis e a maioria dos minerais meta-estāveis de rochas cristalinas na ārea fonte jā tê riam sofrido intenso intemperismo em clima quente e ümido, tendo sido transformados em minerais argilosos e ferruginosos. Estes materiais re manescentes, incluindo os minerais ultra-estāveis e poucos minerais me ta-estāveis, foram rapidamente transportados pela āgua corrente, em meio de baixa seleçäo, e depositados na borda da bacia.

3) Nos subarcōsios do pacote superior da Formação Itararē e maioria dos subarcósios da Formação Aquidauana com granulação e maturidade variāveis, os indices ZTR são muito altos, maior que $84,4 \%$ (tabelas III e IX), e não são significativamente correlacionados com as composições de minerais leves e texturas dos arenitos. Esta anormalidade indica que os materiais destes subarcósios foram fornecidos principalmente por rochas graníticas e metamörficas, quartzitos, e parcialmente por sedimentos do prōprio Itararē e Aquidauana, donde foram herdados e/ou retrabalhados os minerais pesados pré-existentes.

4) Nos quartzo-arenitos finos e subarcōsios com baixa quantidade de feldspa tos, das formações Itararē e Aquidauana, nas regiões de Americana e Ara ras, os îndices ZTR são altos, maior do que $86,3 \%$ (tabelas III e IX), exibindo boa correlaçãoentre as maturidades textural e mineralōgica. Su gerem que os materiais destes arenitos foram dominantemente fornecidos pelos prōprios sedimentos das formações Itararē e Aquidauana e parcial mente derivados de rochas cristalinas, mas transportados por longa dis tância em meio de baixa energia.

5) Nos subarcōsios e quartzo-arenitos das formaçōes Pirambōia e Botucatu, os indices ZTR são muito baixos, com valores menores do que $66,6 \%$ na maioria das regiões e com valores maiores que $83,3 \%$ na parte nordeste da bacia (tabelas V, VII e IX). Aqueles valores baixos não são corre lacionados com as composições de minerais leves e texturas dos arenitos e, por outro lado, os valores altos mostram boa correlação. Isto suge re que os materiais destes arenitos no centro da bacia foram predomi nantemente derivados das rochas cristalinas, enquanto os materiais na borda de bacia, predominantemente derivados de rochas sedimentares 
prë-existentes. Todos os materiais destes arenitos foram fortemente trabalhados por abrasão seletiva em clima semiärido e ārido de ambien tes fluvial e desërtico, assunto este que serā discutido pormenorizada mente no capitulo 7 .

6) Nos arenitos de Formação Bauru, os indices ZTR são geralmente muito baixos, sendo que apenas quatro amostras possuem valores maiores que $81,9 \%$ (tabela IX). Sugerem que os materiais destes arenitos foram deri vados das rochas ricas em minerais instāveis e meta-estāveis e não so freram ações abrasiva e seletiva prolongadas.

\subsection{Minerais e Rochas Fontes}

Os minerais leves, incluindo fragmentos de rochas, e mine rais pesados têm sido usados como guias para estudo de proveniēncia, em bora se deposite maior confiança nestes üitimos.

\subsubsection{Assemblëias de minerais e suas rochas fontes}

Em benefício da interpretação da litologia da rocha fonte, os minerais leves e minerais pesados são usualmente agrupados em assem blēias genëticas como as sedimentares retrabalhadas, metamörficas de baixo e alto grau, igneas siälicas e mäficas, pegmatîticas, vulcãnicas e autigēnicas (tabelas $X$ e XI).

6.4.2. Minerais ultra-estäveis arredondados mascarando suas rochas fontes

0 zircão, em para-xistos e para-gnaisses, tende a ser arre dondado, retendo o arredondamento do zircão da rocha sedimentar origi nal retrabalhada, atē o grau mais alto de metamorfismo pois, aparentamen te,o zircão è extremamente resistente a recristalização(BZatt, 1972). $\bar{A}$ maioria dos zircões em quartzitos e gnaisses na região de I tapira e São João 
Tabela $X$

Assemblēias de minerais leves (incluindo fragmentos de rochas) e suas rochas fontes *

Sedimentos retrabalhados

Metamörfica de baixo grau

Metamörfica de alto grau

Ignea siälica

Ignea mäfica

Pegmatitos

Vulcânica

Autigênico
Glauconita. quartzo arredondado (recrescimen to com abrasão), fragmentos de rochas sedimentares.

Quartzo (tamanho de silte e areia fina), Feldspatos geralmente ausente, fragmentos de ardósios, filitos e metaquartzitos.

Quartzo (variedade metamörfica), feldspato (plagiocläsio alcalino): fragmentos de xistos.

Quartzo (variedade ignea), microclinnio, orto cläsio, fragmentos de rochas siälicas.

Plagioclāsio (intermediärio a cālcico), frag mentos de rochas ĩgneas mäficas.

Quartzo de veio, albita, microclinio.

Quartzo euêdrico (variedade vulcânica), plagiocläsio, sanidina, fragmentos de rochas vulcânicas, vidro vulcânico.

Quartzo, feldspato.

* Modificado de Pettijohn, 1957, Folk, 1968 e Blatt et alli, 1972. 
Tabe la XI

Assemblēias de minerais pesados e suas rochas fontes *

Sedimentos retrabalhados

Metamörfica de baixo grau

Metamörfica de alto grau

Ignea siälica

Ignea mäfica

Pegmatitos

Vuicânica

Autigēnico
Barita, leucoxēnio, rutilo (arredondado), turma lina (arredondado): zircão (arredondado)

Biotita, muscovita, clorita (se clāstico), turmalina (pequeno, marrom, euëdrico), leucoxênio. Actinolita, andalusita, apatita, granada, bioti ta, diopsïdio, epidoto, hornblenda, ilmenita, cianita, magnetita, sillimanita, titanita, estaurolita, zircâo,

Apatita, biotita, hornblenda, ilmenita, monazita, muscovita, rutilo, titanita, zircão (euëdri co), magnetita, turmalina (pequeno, rosa).

Anatäsio, augita, brookita, hiperstênio, hornblenda, ilmenita, magnetita, cromita, leucoxênio, olivina, rutilo, serpentina.

Apatita, biotita, cassiterita, granada, fluorita, monazita, muscovita, topäzio, rutilo, turma lina (azul, indicolita).

Os cristais euëdricos de apatita, augita, bioti ta, hornblenda e zircäo.

Hematita, leucoxēnio, limonita, turmalina, zircão, anatäsio, brookita, pirita, rutilo, titani ta.

* Modificado de Pettijohn, 1957, Hubert, 1971 e Blatt et alli, 1972. 
da Boa Vista são arredondados a bem arredondados (tabela XII). Isto in dica que os minerais ultra-estäveis como zircão, às vezes turmalina e ru tilo arredondados destas formações, poderiam ser predominantemente deriva dos de para-gnaisses, para-xistos, filitos e rochas metassedimentares e parcialmente derivados das rochas sedimentares prë-existentes.

\subsubsection{Rochas fontes}

Considerando as assemblëias de minerais pesados e leves (figuras 2,4 e 6 ) e as feições morfoscōpicas dos minerais (tabelas II a VIII), as rochas fontes dos arenitos estudados poderiam ser as seguintes:

\subsubsection{Arcósios e subarcösios no topo do pacote superior e no pacote inferior da Formação Itararē}

Os minerais leves destes arenitos são caracterizados pela a]ta porcentagem de feldspatos incluindo fragmentos de granito e/ou gnais se, fragmentos de rochas metamörficas, grandes fragmentos de micas e pou cos fragmentos de rochas sedimentares. Os grãos são subangulares a subar redondados. Os minerais pesados destes arenitos são caracterizados pela alta porcentagem de minerais meta-estáveis como granada, apatita e estau rolita. Os grãos são dominantemente subangulares a subarredondados (Pro vincia A). Os minerais ultra-estäveis como zircão, turmalina e rutilo são predominantemente subangulares a arredondados, sendo que os arredonda mentos do zircão são maiores que os de turmalina e rutilo. os minerais opacos como magnetita e ilmenita e leucoxênio são subangulares a subarre dondados. A quantidade de leucoxēnio è sempre maior que a de magnetita e iTmenita. Esses materiais devem ter sido derivados predominantemente de granitos, gnaisses e migmatitos e, em pequena escala, de xistos, fili tos, metassedimentos e rochas sedimentares prē-existentes.

\subsubsection{Quartzo-arenitos da Formação Aquidauăna}

Os minerais leves destes arenitos são caracterizados pela 
Tabe la XII

Composição percentual, arredondamento e häbito cristalino nos minerais pesados das rochas cristalinas do Pre- $€$ Indiviso

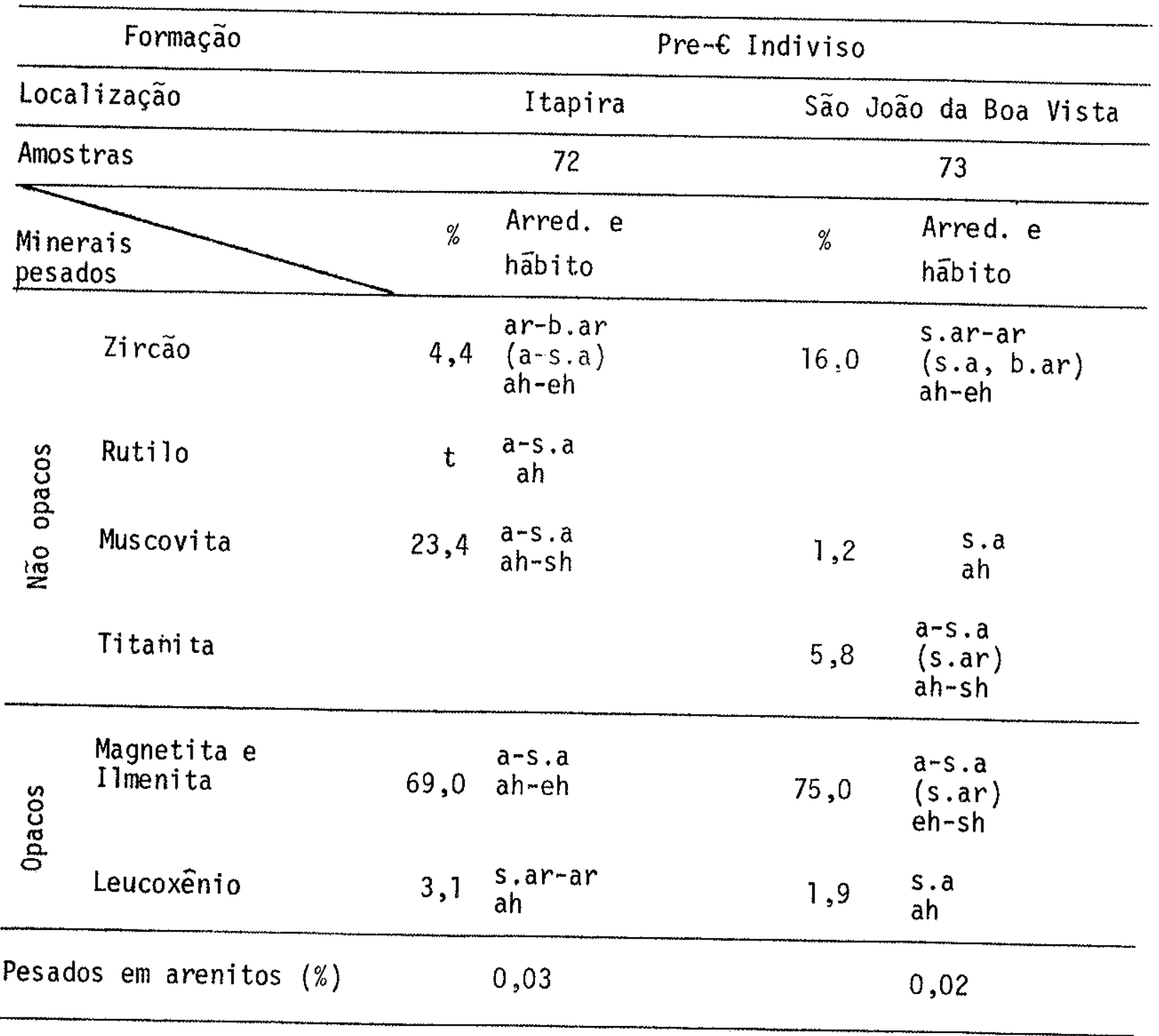

Notas: $t=$ traço; $a=$ angular; $s . a=$ subangular; s.ar = subarredondado: $a r=$ arredondado; $b . a r=$ bem arredondado: $a h=a$ eédrico; $s h=$ subëdrico; eh = euëdrico; $(\ldots)=$ Pouco. 
alta porcentagem de quartzo e poucos felspatos, grandes micas e fragmen tos de rochas sedimentares. Os grãos são subangulares a subarredondados. Os minerais pesados destes arenitos são caracterizados pela alta porcen tagem de minerais opacos como magnetita e ilmenita, leucoxēnio e limonita. Os grãos são principalmente subangulares a subarredondados e subordinada mente arredondados (Provĩncia C). Os minerais ultra-estāveis como zircão, turmalina e rutilo são subangulares a bem arredondados. 0 arredondamento destes minerais è maior na região de Mogi-Mirim que nas regiões de Campi nas, Casa Branca e Mococa. Os minerais meta-estäveis como estaurolita e monazita săo raros. Esses materiais devem ter sido derivados predominan temente de quartzitos, gnaisses, migmatitos e granitos, e poucas rochas sedimentares prë-existentes.

\subsubsection{Subarcōsios do pacote superior da Formação Itararë e maioria dos subarcōsios da Formação Aquidauana.}

Os minerais leves destes arenitos säo caracterizados pela moderada porcentagem de feldspatos e poucas grandes micas, fragmentos de rochas metamörficas e sedimentares prë-existentes. 0s grãos säo suban gulares a subarredondados. Os minerais pesados destes arenitos são carac terizados pela alta porcentagem de minerais ultra-estāveis e/ou pelo alto valor de ZTR (provincias B e C). Os minerais ultra-estāveis como zircão, turmalina e rutilo são subangulares a bem arredondados. Os arredondamen tos destes minerais säo maiores na Formaçäo Itararē que na Formação Aqui dauana, e os de zircão são mais altos que os outros dois. Os minerais opa cos como magnetita e ilmenita e leucoxenio são subangulares a subarredon dados. A quantidade de leucoxênio na Formação Itararē ë sempre maior que a de magnetita e ilmenita. Os minerais meta-estāveis como granada, estaurolita, monazita, cianita e epidoto são raros. Isto indica que os materiais do pacote superior da Formação Itararē devem ter sido derivados predominantemente de granitos, gnaisses, migmatitos, filitos e metassedi mentos e os da Formação Aquidauana, derivados de granitos, gnaisses e mig matitos, ambos os materiais com contribuição de poucos sedimentos préexistentes de Itararë e Aquidauana. 


\subsubsection{Quartzo-arenitos e subarcösios das formações Ita rarē e Aquidauana nas regiões de Americana e Ara ras.}

Os minerais leves destes arenitos são caracterizados pelas altas porcentagens de quartzo, baixa porcentagem de feldspatos, grandes fragmentos de micas e fragmentos de rochas sedimentares. 0s grãos sāo sü bangulares a subarredondados. As assembëias de minerais pesados são seme Thantes as de subarcōsios do pacote superior da Formação Itararē e da For mação Aquidauana. Seus arredondamentos, porēm, são mais altos. Esses mate riais devem ter sido derivados predominantemente de sedimentos mais anti gos das formações Itarare e Aquidauana e parcialmente derivados das mesmas rochas cristalinas acima mencionadas.

6.4.3.5. Subarcösios e quartzo-arenitos das formaçöes $\mathrm{Pi}$ ramböia e Botucatu.

Os minerais leves destes arenitos são caracterizados por mo derada a baixa porcentagem de feldspatos, raros fragmentos de silex e mi cas. Os grãos säo dominantemente subangulares a arredondados na Formação Piramböia e arredondados a bem arredondados na Formação Botucatu. As assemb lé ias de minerais pesados são divididas em duas provĩncias, as quais são in terdigitadas entre as duas formações. A Provĩncia $A$ e caracterizada pela alta porcentagem de minerais meta-estāveis como estaurolita, granada, epi doto e mica, ocorrendo predominantemente na Formação Pirambóia. Seus grãos são angulares a arredondados. Os minerais opacos e ultra-estāveis da Pro vĩncia $A$ são predominantemente arredondados a bem arredondados. A Provín cia $B$ e caracterizada pela alta porcentagem de minerais opacos como magne tita e ilmanita, leucoxênio, hematita e limonita, ocorrendo principalmen te na Formação Botucatu. Os minerais ultra-estäveis da Provĩncia B são predominantemente arredondados a bem arredondados e os opacos são subangu lares a subarredondados. Os indices de ZTR são baixos na parte central da bacia e altos na parte nordeste da borda da bacia. Baseado nessas carac terĩsticas, os materiais dos arenitos de formação Piramböia e Botucatu da parte central da bacia devem ter sido derivados predominantemente de ro chas cristalinas e parcialmente de rochas sedimentares pré-existentes e os da parte nordeste da bacia, predominantemente de rochas sedimentares 
prë-existente e parcialmente de rochas cristalinas. Durante a deposição dos arenitos da Formação Botucatu, teve lugar o vulcanismo na ärea fonte o que forneceu magnetita e ilmenita angulares e euëdricas.

\subsubsection{Arenitos da Formação Bauru}

As assemblëias de minerais pesados são divididos em provincias $A$ e B. A Provincia A apresenta altas porcentagens de minerais instäveis e meta-estäveis como piroxēnio, granada, anfibōlio e cianita, cujas carac terísticas e distribuições foram descritas na seçăo 4.4. Os minerais uI tra-estāveis da Provincia A como zircão, turmalina e rutilo são dominan temente subangulares a bem arredondados. Os minerais opacos como magneti ta e ilmenita e leucoxēnio são dominantemente subangulares a arredondados. A Província B apresenta uma assemblēia composta e variāvel, distribuĩda no pacote superior e inferior da Formação Bauru. Os minerais opacos como magnetita e ilmenita e limonita são subangulares a arredondados. Os mine rais ultra-estāveis como zircão, turmalina e rutilo são subarredondados a bem arredondados. Granada, apatita, estaurolita, cianita, epidoto, tita nita e perowskita, meta-estäveis, são angulares a bem arredondados. Piro xënio e anfibölio, instāveis, săo angulares a arredondados. Os materiais destes arenitos na Província A foram fornecidos predominantemente por ro chas vulcānicas alcalinas, ultra-bäsicas e basalto e, parcialmente, por ro chas metamörficas, İgneas e sedimentares prē-existentes. Os materiais destes arenitos na Provincia B foram fornecidos predominantemente por ro chas metamörficas, ígneas e sedimentares prē-existentes e parcialmente por rochas vulcânicas alcalinas, ultra-bäsicas e basalto. 
7. FATORES GOVERNANDO A OCORRENCIA DE MINERAIS

A composição de arenitos é largamente dependente das rochas fontes, sendo modificadas pelas abrasão seletiva, seleção hidräulica, in temperismo e dissolução intra-estratal. Assim para determinar a proveniēn cia de arenitos, as modificações introduzidas por cada um desses processos tem que ser consideradas conjuntamente.

\subsection{Abrasão seletiva}

A abrasão seletiva poderia resultar em eliminaçäo progres siva e sistemātica dos minerais de baixa dureza e enriquecimento comple mentar dos componentes mais duros. Segundo os trabalhos experimentais so bre resistência abrasiva dos minerais (Friese, 1931, Cozzens, 1931, Thiel, 1945 e Nemec et alli 1978), os mais resistentes à abrasão, em ordem de crescente, são: quartzo, turmalina, microclinio, estaurolita, magnetita e ilmenita, granada, epidoto e zircão.

A intensidade de abrasão seletiva e largamente dependente dos meios de transporte e tamanho dos grãos. Os grãos maiores como sei xos e areias grosseiras, transportados por quaisquer meios de transporte, mostram mudanças composicionais. As areias transportadas prolongadamen te por äguas correntes mostram nenhuma ou poucas mudanças mineralögicas (Russel, 1937, 1939 e Landim et alli 1977) e as transportadas pelo vento mostram grandes mudanças (Pettijohn, 1957 e Folk, 1968).

Durante o transporte e deposição das formações Piramböia e Botucatu, as partículas destes arenitos sofreram fortemente a ação abra siva eólica, os minerais de baixa dureza foram eliminados, permanecendo somente os minerais mais duras como quartzo, microclinio, turmalina, es taurolita, magnetita e ilmenita, granada, epidoto e zircão.

\subsection{Seleção hidräulica}

A seleção de minerais pesados tem sido um problema em es tudos de proveniencia. Fraçōes de diferentes granulometrias, amostradas num mesmo sedimento, possuem assemblēias de minerais pesados diferentes, 
uma vez que são depositadas junto a minerais leves de tamanho hidräulico equivalente. Rittenhouse (1943) propõe o conceito de tamanho hidräulico equivalente dos pesados para resolver o problema de seleçäo hidräulica.Ele mostrou värios fatos em uma mesma amostra: (1) as distribuições granulo mētricas dos minerais pesados formam uma curva acumulativa lisa como a dos minerais leves; (2) todos os minerais pesados são mais finos granulometri camente em relação aos minerais leves; (3) em geral, aumentando 0 pe so especiffico ocorre uma diminuição no tamanho dos minerais pesados; (4) o zircão $(d=4,6) \vec{e}$ menor que a magnetita $(d=5,2)$ e $(5)$ a diferença na inclinação das curvas acumulativas de percentual granulomëtrico indica que os minerais pesados, na mesma amostra, tem seleções diferentes.

os minerais pesados transparentes não micáceos compõem uma suite hidräulica regularmente homogenea na fração de areia muito fina, re duzindo o problema relativo à seleção hidräulica (Hubert, 1971). Fatores poucos conhecidos afetam a ocorrēncia dos minerais pesados de densidade al ta como zircão, magnetita e ilmenita, que se concentram na fraçăo de areias finas (Rittenhouse, 1943). Esta ē a razão pela qual, como constatado em todos os arenitos estudados, os minerais pesados zircão e especialmente mag netita e ilmenita, são sempre mais abundantes que outros minerais pesados na fração de areia muito fina.

\subsection{Intemperismo}

0 intemperismo pode modificar consideravelmente a compo sição mineralógica de um sedimento. Sua influência vai depender das con dições climäticas da ārea fonte e sītio deposicional.

Os sedimentos da Formação Aquidauana foram derivados das rochas cristalinas intemperizadas e sedimentos do pröprio Aquidauana e ro chas sedimentares prë-existentes, sendo depositados em ambientes oxidan tes, parcialmente expostos à superfície, sofrendo mais a influência do in temperismo quïmico. Este fato estā relacionado com discordāncias existen tes nesta unidade estratigräfica e no contato com formações superpostas. Portanto, os minerais mäficos da Formação Aquidauana foram fortemente alte rados para ōxido-hidrōxidos de ferro que, disseminados, cimentaram os grãos mais grosseiros e emprestaram a cor vermelho-tijolo a estes sedimentos, os quais ocorrem nas partes mais marginais da bacia e partes basais da For mação Itararë em Säo Paulo e Paranä (Tommasi, 1973, Soares e Landim, 1973). Estes depösitos representam em mëdia $1 / 3$ de seção de Formação Itararē na 
faixa de afloramentos do flanco leste da bacia (Soares et azzi, 1974).

Anteriormente à deposição dos sedimentos da Formação Aqui dauana, as rochas do Embasamento, situadas a nordeste e leste da bacia,te riam sido expostas à superfície terrestre por longo perīodo geolōgico, so frendo forte atuação intempērica. Nestas condições, as rochas da ärea fon te devem ter sido intemperizadas atē algumas centenas de metros de profun didade. Os minerais instäveis e meta-estāveis destas rochas foram trans formados total ou parcialmente em minerais de argilas e/ou öxido-hidrōxí dos de ferro e aluminio, dependendo das profundidades de intemperismo.

os sedimentos da Formação Itararē foram derivados de ro chas frescas ou rochas pouco intemperizadas, remanescentes. Dessa forma, não houve tempo para atuação intempērica e formação de grandes discordān cias, tendo sido os sedimentos depositados rapidamente.

os sedimentos das formações Piramböia e Botucatu foram de rivados predominantemente de rochas do Embasamento Cristalino e rochas se dimentares prē-existentes e depositados em bacia estāvel, em clima se mi-ärido a ärido. Nestas condições, os materiais destes sedimentos näo sofreram grande atuação de intemperismo quĩmico. Os grãos dos arenitos das formações Pirambóia e Botucatu são comumente envolvidos por uma fina peli cula de öxido-hidrōxidos de ferro, precipitados de äguas capilares, que dão a estes arenitos a coloração marrom-avermelhada.

\subsection{Dissolução intra-estratal}

Alguns grãos de minerais leves como quartzo, feldspato e si lex apresentam-se com inïcio de corrosão e superfĩcies conncavas ou serri Thadas, às vezes substituĩdo por sericita e/ou calcita. Os minerais pesa dos instāveis e meta-estāveis como piroxēnio, anfibölio, estaurolita e granada sempre mostram forma serrithada e marcas de corrosão; alguns grãos de piroxênio são substituĭdos por calcita. Estas evidências indicam que a ação de soluções intra-estratais ocorreu nas formações estudadas.

A maioria dos minerais meta-estāveis e instāveis nessas for mações como estaurolita, granada, apatita, piroxênio e anfibōlio mostra que a dissolução intra-estratal não foi um importante processo geológico. Se este processo fosse efetivo, as quantidades de minerais meta-estāveise instāveis deveria aumentar da Formação Itararê para Formação Bauru. 
8. CONCLUSOEES

8.1. Tipos de rochas

Os arenitos das formações estudadas são classificados como
arcōsios, subarcōsios e quartzo-arenitos com maior quantidade presente em
feldspatos do que em fragmentos de rochas.

8.2. Provïncias mineralögicas

As provĩncias mineralōgicas das formaçōes Itararē e Aquidaua na säo divididas em três: provīncias A, B e C. A Provīncia A ocorre domi nantemente no pacote inferior da Formação Itararē, a Provincia $B$ no paco te superior da Formação Itararē e a Provĩncia C na Formação Aquidauana. ES tas três provĩncias são interdigitadas.

As provĩncias mineralögicas das formações Piramböia e Botuca tu säo divididas em duas: provincias $A$ e $B$. A Provincia A ocorre dominan temente na Formação Pirambóia e a Província B na Formação Botucatu. Estas duas provĩncias são interdigitadas tambëm.

As provincias mineralōgicas da Formação Bauru são divididas em duas: provĩncias A e B. A Provincia A ocorre dominantemente na base do pacote superior da Formação Bauru na região de 01 ímpia a Santa Adēlia e a Provincia $B$ nos pacotes superior e inferior da Formação Bauru.

As provincias dos minerais pesados nos arenitos destas for mações foram dominantemente controladas pela intensidade de tectonismo, mu dança progressiva e clima na ärea fonte.

\subsection{Maturidade em arenitos}

As maturidades textural e mineraiögica, referentes aos mine rais leves dos arenitos, sāo representadas por quatro estāgios: imaturo, submaturo, maturo e supermaturo. A maturidade mineralögica referente aos minerais pesados transparentes não micāceos $\vec{e}$ quantitativamente definido 
pelo indice zircão - turmalina - rutilo (ZTR).

As maturidades textural e mineralógica para os minerais le ves e pesados nesses arenitos nem sempre se correlacionam, indicando que são controladas por fatores diferentes. A maturidade textural desses are nitos é dominantemente controlada pelo tipo e intensidade de energia dos meios de transporte; a maturidade mineralógica relativa aos minerais leves é controlada pelas rochas e intemperismo na ārea fonte: e a maturidade mi neralógica referente aos minerais pesados é controlada também pelas rochas e intemperismo na ārea fonte. Estes pesados são modificados por abrasão seletiva mas no caso dos minerais ultra-estāveis eles podem manter seu ar redondamento original de rochas metamörficas.

8.4. Fatores governando a ocorrēncia de minerais

A ocorrência de minerais foi modificada por quatro fatores: abrasão seletiva, seleção hidräulica, intemperismo e dissolução intra-es tratal.

Antes e/ou durante a deposição da Formação Aquidauana, as rochas na ārea fonte foram fortemente intemperizadas, transformando total mente os minerais instāveis e parcialmente os minerais meta-estāveis a mi nerais de argila e óxido-hidrōxidos de ferro.

Durante o transporte e deposição das formações Pirambōia e Botucatu, os grãos destes arenitos sofreram fortemente a açäo abrasiva eolica e os minerais de baixa dureza foram eliminados, permanecendo somente os minerais mais duros.

Os minerais pesados de densidade alta como zircão, magneti ta, ilmenita e leucoxênio são sempre mais abundantes que outros na fração de areia muito fina, graças a ação da seleção hidrāulica.

A ação de soluções intra-estratais ocorreu nestas formações, porēm não de modo importante.

8.5. Rochas fontes dos arenitos e sua condiçöes deposicionais

Baseado nas caracteristicas dos minerais pesados e leves e nas variações de provĩncias dos minerais pesados nestas formações, e considerando-se as maturidades em arenitos e os fatores governando a ocor 
rência de minerais, as rochas fontes destes arenitos e suas condiçöes de posicionais são as seguintes, as quais estão tambēm de acordo com obser vações geológicas de autores anteriores:

\subsubsection{Formações Itararē e Aquidauana}

Antes da deposição dos sedimentos da Formação Aquidauana, - Embasamento Cristalino, constituído por rochas granīticas Brasilianas, situadas ao nordeste da bacia, e por metassedimentos de Grupo São Roque e as rochas graniticas Brasilianas, situadas a leste, jā estavam expostas $\bar{a}$ superfície por longo periodo geológico, tendo sofrido forte atuaçäo intem përica. Estas rochas devem ter sido intemperizadas atē algumas centenas de metros de profundidade. Os minerais instäveis e meta-estäveis destas rochas foram transformados total ou parcialmente em minerais de argi la e/ou ōxido-hidrōxidos de ferro e alumīnio, dependendo da profundidade de intemperismo.

No inĩcio da deposição da Formaçāo Aquidauana, os materiais foram derivados predominantemente das rochas cristalinas intemperizadas e parcialmente de rochas sedimentares prë-existentes, tendo sido depositados em ambiente fluvial com influencia glacial.

Depois, as rochas cristalinas situadas ao sudeste da bacia sofreram violenta deformação vertical e grandes falhamentos, acompanhada de grande subsidēncia na região do mëdio Rio Tietē e decrescendo para o nordeste da bacia. 0correu consequentemente, uma grande ingressão marinha. Dessa forma, os sedimentos do pacote inferior da Formaçäo Itararē foram derivados predominantemente das rochas situadas a sudeste da bacia, consti tuĩdas por rochas cristalinas frescas, poucas rochas metassedimentares e rochas sedimentares prë-existentes, sendo depositadas em ambiente marinho de āguas relativamente profundas a rasas, com forte influēncia glacial. Os sedimentos da Formação Aquidauana, correspondentes äqueles do pacote infe rior da Formação Itararē, foram derivados predominantemente das rochas si tuadas a nordeste da bacia, constituïdas por rochas cristalinas intemperi zadas, poucos sedimentos prë-existentes e sedimentos da pröpria Formação Aquidauana, sendo depositados em ambientes de planïcie de mare a marinho raso e fluvial, com influência glacial.

0 desenvolvimento do arqueamento de Ponta Grossa e a re-es truturação da bacia ocasionaram a regressão marinha na bacia e progradação da sedimentação continental (Soares et alli 1974). Sob tais condições, os sedimentos do pacote superior da Formação Itararē foram derivados predomi nantemente das rochas situadas a sudeste da bacia, constituĩda por rochas 
metassedimentares do Grupo São Roque, rochas granïticas Brasilianas, sedi mentos prē-existentes e da prōpria Formação Itararē, sendo depositados em ambiente marinho raso, deltäico e fluvial, com influência glacial. Os sedimentos da Formação Aquidauana, correspondentes ao pacote superior da Formação Itararē, foram derivados predominantemente das rochas situadas a nordeste da bacia, constituídas por sedimentos da pröpria Formação Aqui dauana, poucas rochas cristalinas e rochas sedimentares prē-existentes, sen do depositados em ambientes flüvio-glacial e de lago glacial.

\subsubsection{Formações Pirambōia e Botucatu}

Durante a deposiçäo das formaçōes Piramböia e Botucatu, as āreas fontes foram os escudos estāveis de rochas cristalinas situadas a leste e sudeste da bacia e sedimentos prë-existentes e rochas cristali nas situadas a nordeste. Os sedimentos das formações Pirambōia e Botuca tu da parte central da bacia devem ter sido derivados predominantemente das rochas cristalinas e parcialmente das rochas sedimentares prë-existen tes e os da parte nordeste da bacia, predominantemente derivados das ro chas sedimentares prë-existentes e parcialmente das rochas cristalinas.

Ao tempo da deposição da Formação Botucatu, teve Tugar um vulcanismo bāsi co na ārea fonte, o que propiciou o fornecimento de magnetita e ilmenita angulares e euëdricas.

Os arenitos da Formação Pirambōia foram depositados em am biente fluvial com forte influência eōlica e os da Formação Botucatu de positados em ambiente eölico com forte influência fluvial.

\subsubsection{Formação Bauru}

No inĩcio da deposição do pacote inferior da Formação Bau ru no nordeste do Estado de São Paulo, os escudos estāveis de rochas cris talinas situadas ao norte, e as rochas sedimentares prë-existentes mais as rochas cristalinas situadas a leste da bacia Bauru compunham a princi pal fonte dos materiais dos arenitos que foram depositados em ambiente fluvial. Atē a deposição da base do pacote superior da Formação Bauru, a ārea fonte localizada ao norte da bacia foi ativa e elevada pelo soergui mento do Arco da Canastra, associada a uma intensa atividade vulcänica al calina e ultrabāsica e tambëm, às lavas basälticas da Formação Serra Ge 
ral que, a esse tempo, foram expostas acima do nivel erosivo na margem nor te da bacia. Consequentemente, o intemperismo, erosao e deposição, rea lizados em ambiente fluvial, formaram os arenitos tufāceos da Formação Bauru que contēm muitos minerais pesados instāveis e meta-estāveis. En quanto a maioria das rochas vulcānicas bāsica, alcalina e ultrabāsica de ram origem aos sedimentos da base do pacote superior da Formação Bauru, os sedimentos restantes desse pacote superior tiveram proveniēncia simi lar a do pacote inferior da Formação, com pouca contribuição vulcânica bäsica, alcalina e ultrabäsica. 


\section{AGRADECIMENTOS}

Quero deixar registrado os meus sinceros agradecimentos ao Professor Doutor Paụlo Milton Barbosa Landim, pela orientação e estimulo que dedicou a esta pesquisa, bem como a revisão do texto em português.

A Professora Maria Rita Caetano Chang, um agradecimento es pecial, pela leitura crïtica do manuscrito, valiosas discussões e revisão minuciosa do texto em português.

Ao Professor Doutor Paulo Cesar Soares, pelas valiosas dis cussões e contribuição nos trabalhos de campo, o meu muito obrigado.

A Professora Neide M.N. Gonçalves pela preparação das amos tras da Formação Bauru e ao Geōlogo Augusto E. Meyer Jr. pela cooperação nos trabalhos de campo, o meu muito obrigado.

Aos Professores Armarido Márcio Coimbra, Jairo Roberto Jime nez Rueda, Dr. Josē Moacyr Vianna Coutinho, Dr. Eberhard Wernick, Dr. Asit Choudhuri e Dr. Heinz Ebert, agradeço pelas determinações e/ou confirma ções de minerais que se mostraram difíceis de identificação.

Ao Instituto de Geociencias e Ciências Exatas da UNESP, em especial ao Departamento de Geologia Geral e Aplicada, por ter proporciona do as condições de trabatho que propiciaram a realização deste trabalho.

A Sra. Maria Cēlia Zadra Schmidt pela preparação de algu mas amostras e ao Sr. Antonio Carlos Bueno de Moraes, pela preparação das làminas, o meu muito obrigado.

As Srtas. Margarida de Paula Caraça e Doraci Dionizio, e ao Sr. Antonio Cezärio Porta Jūnior agradeço, respectivamente, pela dati lografia e desenhos realizados. 
10. BIBLIOGRAFIA

Amaral, S.E. - 1961 - Silicificação intersticial de arenitos de Sergipe(Sê rie Barreiras) e de Varnhagen, SP (Sërie Itararē)-Bol.Soc.Bras.Geol., 10(1): 79-99.

Amara1, G., Cordani, U.G., Kawashita, K. e Reynolds, J.H. - 1966 - Potas sium Argon ages of basaltic rocks from Southern Brazil-Geoch. Cosmoch. Acta, 30(2): 159-189.

Andrade, S.M. e Soares, P.C. - 1971 - Geologia de semi-detalhe do Cen tro-Leste de São Paulo - Petrobrās-Desu1, Re1. 407, 52p.

Artur, A.C., Wernick, E. e Kawashita, K. - 1979 - Dobramentos superimpos tos na região de Itapira (SP): Caracterização e cronologia - 20 Sim pósio Reg. Geol., 1: 59-69.

Baturin, V.P. - 1931 - Petrography of the sands and sandstones of the productive series-Bu11. Trans. Azerbaidjan Petrol. Inst., 1:1-95.

Blatt, H., Middleton, G. and Murray, R. - 1972 - Origin of sedimentary rocks - Prentice-Hall, Inc., Englewood cliffs, 634 p.

Boswe11, P.G.H. - 1923 - The petrography of the Cretaceous and Tertiary outliers of the west of England - Quart. Jour.Geol.Soc., 79: 226.

Carvalho, A.M.V. - 1954 - Contribuição ao estudo petrogräfico do arenito Botucatu no Estado de São Paulo - Bol. Soc.Bras.Geol., 3(1) 51-72.

Coimbra, A.M. - 1976 - Arenitos da Formaçăo Bauru: Estudo de äreas-fonte

- Dissertação de Mestrado, Instituto de Geociências, USP, São Paulo.

Cozzens, S.B. - 1931 - Rates of wear of common minerals - Wash. Univ. Stu dies, Sci. and Technol ., (5, new series): 71-80.

Edelman, C.H. - 1933 - Petrologische provinces in het Nederlandse Kwartair- 
Center Publishing Co., 104 p.

Evans, P., Hayman, R.J. and Majeed, M.A. - 1933 - The graphical represen tation of heavy mineral analyses - World Petrol Congr. Proc., 1:251256.

Fiori, A.P. - 1977 - Estratigrafia do Grupo Tubarão (Formação Aquidauana) na região sudoeste do Estado de Minas Gerais - Dissertação de Mes trado, Instituto de Geociēncias, USP, São Paulo.

Folk, R.L. - 1968 - Petrology of sedimentary rocks - Hemphill's, 170 p.

Friese, F.W. - 1931 - Investigation of the wearability of minerals during transportation in water - Mineralog. Petrog. Mitt., 41: 1-7.

Goldish, S.S. - 1938 - A study in rock weathering - Jour.Geo1., 46:17-58.

Hubert, J.F. - 1962 - A zircon-tourmaline-rutile maturity index and the interdependence of the composition of heavy mineral assemblages with the gross composition and texture of sandstones - Jour.Sed.Petrol., 32(3): $440-450$.

Hubert, J.F. - 1971 - Analysis of heavy-mineral assemblages (in Carver, R.E. - Procedures in sedimentary petrology) - Wiley interscience, 453-476.

Krynine, P.D. - 1948 - The megascopic study and field classification of sedimentary rocks - Jour. Geo1., 56: 130-165.

Landim, P.M.B., Wu, F.T. e Meyer Jr. A.E. - 1977 - Contribuição ao estudo dos minerais pesados do leito do Rio Amazonas - Cienc.Cult., resumos, 29 (Sup1. 7): 514.

Leinz, V. - 1949 - Contribuição à geologia dos derrames basā7ticos no Sul do Brasil - Bol.Fac.Ciēnc.Let.,USP, 103(Geo1. 5): 1-61.

Milner, H.B. - 1962 - Sedimentary Petrography - AlTen and Unwin Ltda.,715p. 
Nemec, H., Nemec, W., e Porebski, S.J. - 1978 - Weissliegendes sandstones: A transition from fluvial-aeolian to shallow-marine sedimentation (Permian of the Fore - Sudetic Monocline) - Rocznik Polskiego Towarzystwa Geologicznego, Annales de La Sociēté Gēologique de Po logne, XLVIII (1): 73-97.

Paraguassu, A.B. - 1968 - Contribuição ao estudo da Formação Botucatu: Sedimentitos aquosos estruturas sedimentares e silicificação - Tese de Doutoramento, Esc.Eng.São Carlos, USP.

Penalva, F. e Wernick, E. - 1973 - Compartimentação tectōnica em parte do Prē-Cambriano paulista - XXVII Gongr.Bras.Geol. Resumo das comunica ções, (1): 128-129.

Pettijohn, F.J. - 1957 - Sedimentary rocks - Harper \& Brother, 20 ed.,718 p.

Rittenhouse, G. - 1943 - The transportation and deposition of heavy mine rals - Bul1.Geol.Soc.Am., 54: 1725 - 1780.

Russe1, R.D. - 1937 - Mineral composition of Mississippi River sands Bu11. Geol.Soc.Am., 48: 1307-1348.

Russel, R.D. - 1939 - Effects of transportation on sedimentary particles, in recent marine sediments, Tulsa - Amer. Assoc.Petroleum Geologists. 32-47.

Sindowski, F.K.H. - 1949 - Results and problems of heavy mineral analysis in Germany: a review of sedimentary-petrological papers, Jour. Sed. Pe trol., 19: 3-25.

Soares, P.C. - 1973 - 0 Mesozóico Gondwānico no Estado de São Paulo - Te se de Doutoramento, Departamento de Geologia e Mineralogia, F.F.C.L. Rio Claro.

Soares, P.C. e Landim, P.M.B. - 1973 - Aspectos regionais da estratigra 
fia da Bacia do Paranā no seu flanco Nordeste - An. XXVII Congr.Bras. Geo1. 1: 243-256.

Soares, P.C. e Landim, P.M.B. - 1976 - Comparison between the tectonic evolution of the intracratonic and marginal basins in South Brazil International Symposium on Continental Margins of Atlantic Type. An. Acad. Bras. Ciēn. 48 (sup1.): 313-324.

Soares, P.C., Sinelli, 0., Penalva, F., Wernick, E., Souza, A. e Castro, P.R.M. - 1973 - Geologia do Nordeste do Estado de São Paulo - An. XXVII - Congr.Bras.Geo1., 1: 209-228.

Soares, P.C., Landim, P.M.B. e Fūifaro, V.J. - 1974 - Avaliação prelimi nar da evolução geotectōnica das bacias intracratōnicas brasileiras An. XXVIII Congr.Bras.Geo1., 4: 61-83.

Soares, P.C., Landim, P.M.B., Sine11i, 0., Wernick, E., Wu, F.T. e Fiori, A.P. - 1977 - Associações litológicas do Subgrupo Itararé e sua in terpretação ambiental - Rev. Bras. Geol., 7: 131-149.

Thie1, G.A. - 1945 - Mechanical effects of stream transportation on mine ral grains of sand size (abstract) - Bul1.Geol.Soc.Amerc., 56: 1207.

Tommasi, E. - 1973 - Geologia do flanco sudeste da Bacia do Paranā (RS, SC e PR) - XXVII Congr.Bras.Geol., Resumo das Comunicações (2): 147148.

Wu, F.T. e Soares, P.C. - 1974 - Minerais pesados nas formações Pirambōia e Botucatu - An. XXVIII Gongr.Bras.Geo1. 119-127. 


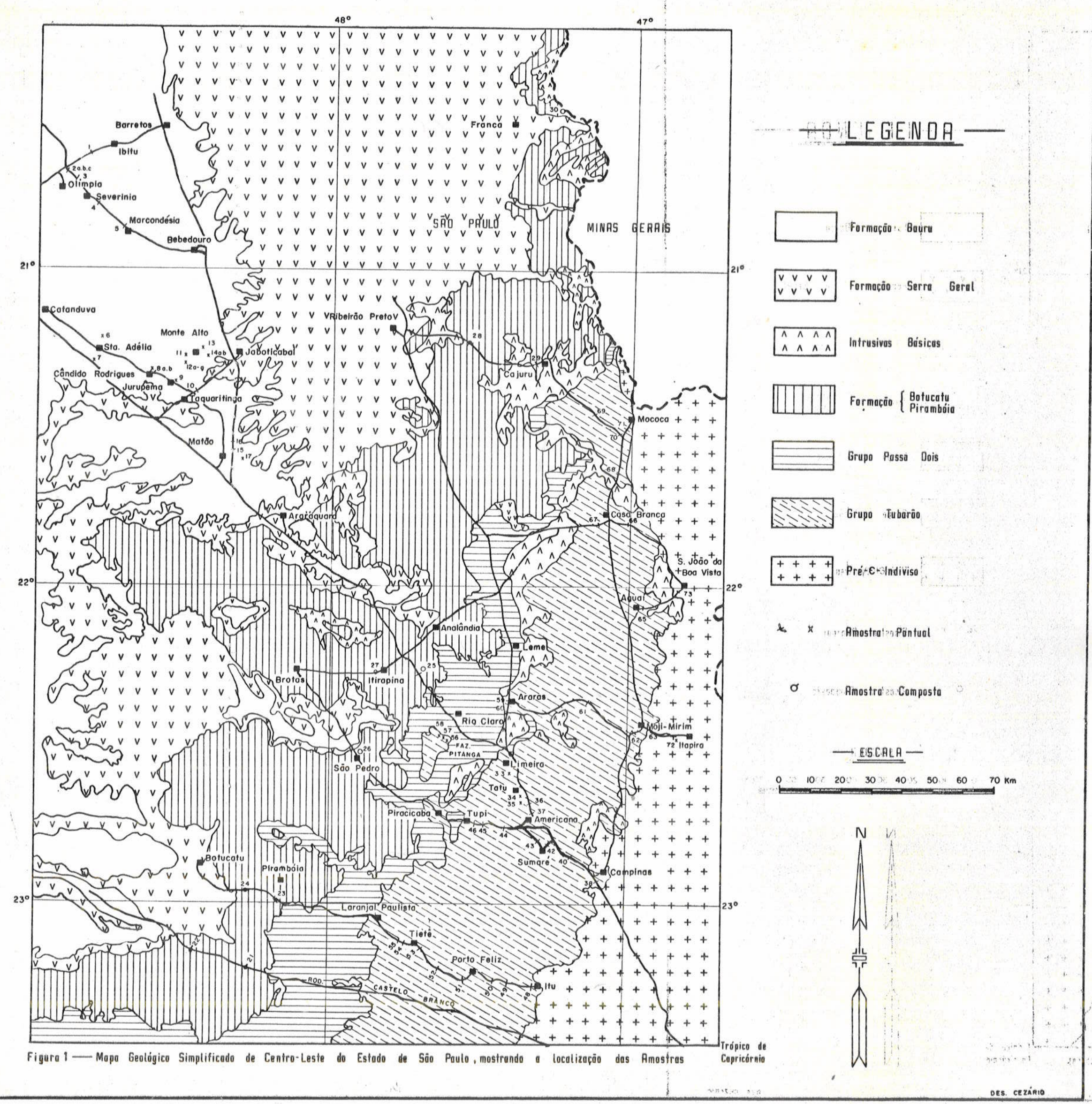

